\title{
A szándéktól az önszabályozásig. A viselkedés elórejelzésének modelljei egészségviselkedések esetében
}

\author{
BERKES TÍMEA* \\ Eötvös Loránd Tudományegyetem, Egészségfejlesztési \\ és Sporttudományi Intézet, Budapest
}

(Beérkezett: 2014. szeptember 18.; elfogadva: 2015. március 30.)

\begin{abstract}
Elméleti háttér: Az egészségviselkedések előrejelzése elméleti és gyakorlati szempontból is fontos az egészségpszichológia számára; e célból számos pszichológiai modell született. Cél: A tanulmány célja, hogy a szándék-viselkedés kapcsolatára épülő hagyományos modelltól (tervezett viselkedés elmélete, Ajzen, 1991) - a modell részletes bemutatása után eljusson a szándék kialakulása utáni szakaszt önszabályozási folyamatként értelmező modellig, az önszabályozás idóbeli elméletéig (Hall \& Fong, 2007). Módszer: Narratív áttekintés. Eredmények: A metaelemzések szerint a modell a szándék varianciájának 39-44\%-át, a viselkedés varianciájának pedig 19-34\%-át magyarázza. A viselkedés megmagyarázott varianciája nagymértékben függ a vizsgált viselkedéstól, az ezzel kapcsolatos eredmények azonban ellentmondásosak. Az empirikus eredmények ismertetése után az észlelt viselkedési kontroll fogalmával, a viselkedés két prediktorának szerepével, valamint az attitúd és a szubjektív norma komponenseivel kapcsolatos vitatott kérdéseket tárgyalom. A korábbi viselkedés a jövóbeli viselkedés legjobb prediktora; az ezzel kapcsolatos empirikus eredmények és elméleti megfontolások bemutatása után a szándék kialakulása utáni szakaszt önszabályozó folyamatként mutatom be. Az önszabályozás erómodellje szerint az önszabályozó kapacitás korlátozott, így az önszabályozást igényló helyzetek lemeríthetik azt. Az önszabályozás fiziológiai szabályozása összetett; a szabályozásban részt vevô agyterületek megegyeznek a végrehajtó funkciók szabályozását végzố agyterületekkel. A glükóz önszabályozásban betöltött szerepe viszont nem tekinthetô igazoltnak. Az önszabályozás idóbeli elmélete a szakirodalom eddigi eredményeit integrálja. A szándék kialakulása utáni idószakot az önszabályozás biológiai alapjaival, valamint a korábbi viselkedéssel is kiegészíti. A modell feltételezi, hogy a szándék függ attól, hogy a viselkedés pozitív és negatív következményeit idôben milyen távolságra helyezzük a viselkedéstól. Következtetések: A szándék kialakulása utáni idôszakban érdemes egyéb tényezóket is figyelembe venni. Az önszabályozás idôbeli elmélete ígéretesen kísérli meg integrálni a szakirodalom eddigi eredményeit; gyakorlati igazolása a kutatás jelenlegi feladata.
\end{abstract}

Kulcsszavak: viselkedésváltozás, szándék-viselkedés kapcsolat, önszabályozás, korábbi viselkedés, tervezett viselkedés elmélete, egészségviselkedés

\footnotetext{
* Levelezési cím: Eötvös Loránd Tudományegyetem, Egészségfejlesztési és Sporttudományi Intézet, 1117 Budapest, Bogdánfy Ödön u. 10. E-mail: berkes.timea@ppk.elte.hu
} 


\section{A tervezett viselkedés elmélete}

Az egészségviselkedések (McEachan, Lawton, \& Conner, 2010) megvalósítása - mind a viselkedésváltoztatás, mind az egészségviselkedés hoszszú távú fenntartása (Rothman, Baldwin, Hertel, \& Fuglestad, 2011) - kiemelt jelentôségú mind a pszichés jóllét és megfeleló életminôség, mind a betegségek megelózése szempontjából. A pszichológiai szakirodalom régóta keresi a viselkedés elórejelzését, illetve módosítását lehetôvé tevő tényezóket. E tanulmány célja kettôs. A tanulmány elsô részében az egyik legismertebb és leggyakrabban alkalmazott modellel, Ajzen tervezett viselkedés elméletével kapcsolatos fontosabb empirikus eredményeket és szakirodalmi vitákat mutatom be. Ez a modell a szándék-viselkedés kapcsolat hagyományos felfogására épül; ebból kiindulva a tanulmány a második részében a modell egy javasolt kiegészítésén (korábbi viselkedés szerepe) és az önszabályozás egyes kérdéseinek tárgyalásán keresztül eljut a viselkedésváltozást önszabályozási folyamatként tételezó újabb elméletig (az önszabályozás idóbeli elmélete).

\subsection{A tervezett viselkedés elméletének bemutatása}

A tervezett viselkedés elmélete (Theory of Planned Behaviour - TPB; Ajzen, 1991; 1. ábra) az emberi viselkedés, köztük az egészségviselkedések elórejelzésére alkalmazott egyik legismertebb, leggyakrabban kutatott elmélet. A tervezett viselkedés elmélete általános, tartalomtól független modell (Ajzen, 1998), tehát nem kifejezetten az egészségviselkedések magyarázatára jött létre. Egy adott viselkedés specifikus kontextusban történó megjelenésének előrejelzésére és magyarázatára törekszik (Ajzen, 1991), ezért a modell használata során a viselkedést és a modell összes elemét a kontextuális tényezók pontos megadásával konkretizáljuk (lásd késóbb a megfelelés vagy kompatibilitás elvét; Ajzen, 2012; Ajzen \& Fishbein, 2005; Francis és mtsai, 2004).

Az elmélet szerint az emberi viselkedés célirányultsága miatt a viselkedés közvetlen meghatározója a szándék (intention; Ajzen, 1991, 1998), ami egyfajta motivációs tényezót jelent: azt jelzi, hogy a személy mennyi erôfeszítést hajlandó tenni a viselkedés végrehajtása érdekében. İgy minél erôsebb a szándék egy viselkedés végrehajtására, annál valószínúbben következik be a viselkedés (Ajzen, 1991). A szándék a viselkedés oki tényezóje; ez azt is jelenti, hogy ha a szándékot erôsítjük, akkor ezzel a viselkedés megjelenésének valószínúségét növeljük (Ajzen, 2012). Azokban az esetekben, amikor a viselkedés megvalósítása teljesen a személy kontrollja alatt áll, a 


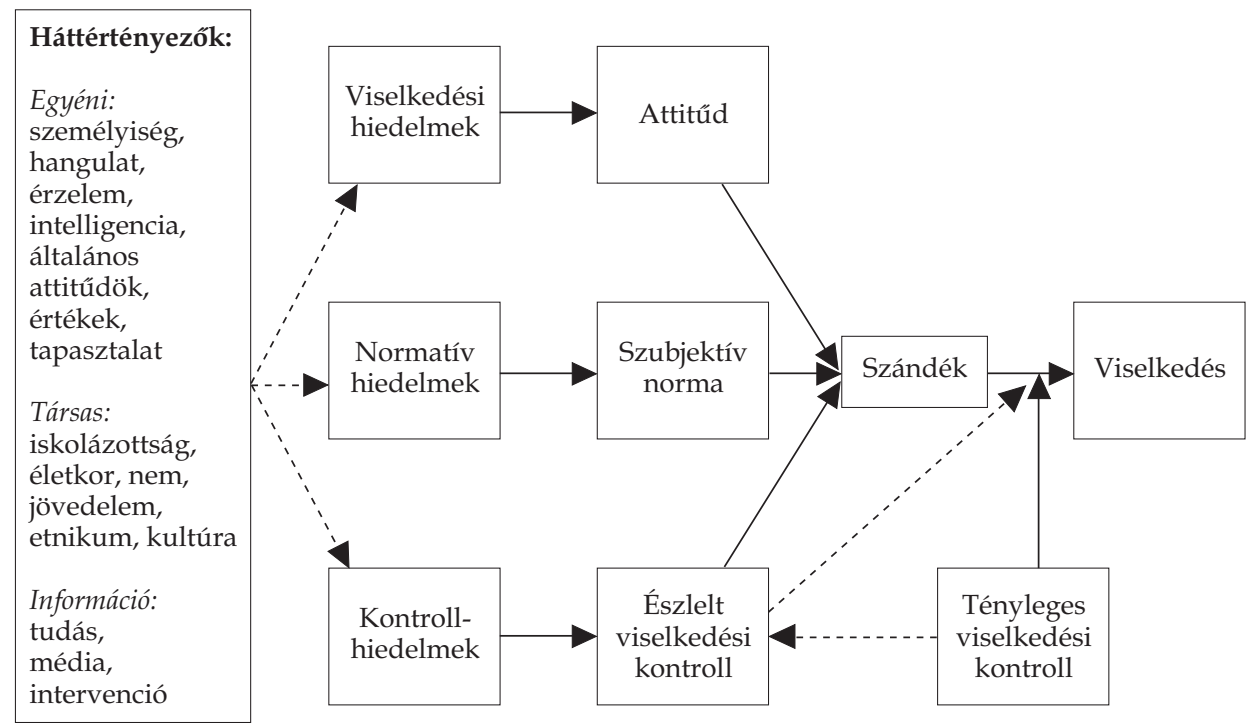

1. ábra. A tervezett viselkedés elmélete (Ajzen \& Fishbein, 2005, 194. o. alapján

szándék önmagában elóre jelzi a viselkedést (Ajzen, 1991), ahogy azt a modell elózménye, az indokolt cselekvés elmélete (Theory of Reasoned Action; Madden, Ellen, \& Ajzen, 1992) feltételezte. A személy kontrollja azonban többnyire nem teljes, mert a viselkedés megvalósítására egyéb tényezók is hatnak. Emiatt egészítette ki Ajzen az indokolt cselekvés elméletét az észlelt viselkedési kontroll (perceived behavioural control) fogalmával, amit a szándék mellett a viselkedés másik meghatározójának tekint (Ajzen, 1991, 2002a). A fogalom összetett, pontos tartalmára vonatkozóan eltéró meghatározásokat olvashatunk. Jelenti azt, hogy a személy mit gondol arról, hogy a viselkedést mennyire lesz könnyú vagy nehéz végrehajtani (Ajzen \& Madden, 1986), illetve, hogy az illetố mennyire érzi magát képesnek az adott viselkedés végrehajtására (Ajzen, 1991).

Fenti meghatározásokból úgy túnik, mintha a viselkedés végrehajtásának észlelt nehézsége és az énhatékonyság az észlelt viselkedési kontroll kétféle meghatározása lenne. Máshol azonban Ajzen ezt a két fogalmat egy tényezőnek tekinti és énhatékonyságnak nevezi; az észlelt viselkedési kontroll másik elemének pedig a viselkedés kontrollálhatóságát tartja (Ajzen, 2002a); ebból a két elemból áll hierarchikus elrendezésben az ész-

\footnotetext{
${ }^{1}$ Ajzen és Fishbein (2005) ábrája szerint az észlelt viselkedési kontroll és a tényleges viselkedési kontroll a szándék-viselkedés kapcsolatot befolyásolja. A modell gyakoribb ábrázolása (pl. Ajzen, 1991, 182. o.) szerint az észlelt viselkedési kontroll közvetlenül a viselkedéssel áll kapcsolatban. A tényleges viselkedési kontrollt többnyire nem tüntetik fel az ábrákon, mivel meghatározása és mérése egyaránt problémás (részletesen lásd a szövegben).
} 
lelt viselkedési kontroll. Az elmélethez tartozó kézikönyv is ezt a felfogást tükrözi: az észlelt viselkedési kontroll „,annak a mértéke, amennyire a személy képesnek érzi magát a cselekvés végrehajtására", és két aspektusa van: mennyire érzi úgy a személy, hogy a viselkedés a kontrollja alatt áll, illetve mennyire biztos abban, hogy képes lesz a cselekvés végrehajtására (Francis és mtsai, 2004, 9. o.); utóbbiba tartozik a viselkedés észlelt nehézsége is (uo., 21. o.). Az észlelt viselkedési kontroll az elmélet egyik legvitatottabb eleme, erról részletesen lásd késóbb (1.3.1. rész).

A modellben helyet kapott a viselkedés feletti tényleges kontroll, ami a szándék-viselkedés kapcsolatot moderálja olyan módon, hogy a szándék viselkedésre gyakorolt hatása erôsebb, amikor a tényleges kontroll nagyobb (Ajzen \& Fishbein, 2005). A tényleges kontroll a személy rendelkezésére álló, a viselkedés megvalósításához szükséges forrásokat és lehetôségeket (Ajzen, 1991), konkrétabban a rendelkezésére álló információt, képességeket, a társas támogatás elérhetôségét, illetve külsố akadályok hiányát (Ajzen, 2012) jelenti. A tényleges kontrollnak azonban mind a tartalma, mind a mérése problémás: többnyire nem ismerjük az összes releváns tényezôtt, ami hatást gyakorolhat a viselkedés végrehajtására, ezért mérni is csak bizonyos aspektusait tudnánk (Ajzen \& Fishbein, 2005). Mindezek miatt a kutatásokban többnyire az észlelt viselkedési kontroll helyettesíti a tényleges viselkedési kontrollt. Minél pontosabb és reálisabb az észlelt viselkedési kontroll, annál inkább megfeleltethetó a tényleges kontrollnak (Ajzen, 2002a).

A tervezett viselkedés elmélete szerint tehát egy viselkedés megvalósulását a szándék és az észlelt viselkedési kontroll jelzi előre, a kettő aránya pedig attól függ, mennyire befolyásolják a viselkedés megvalósítását olyan tényezók, melyekre a személynek nincs hatása (Ajzen, 1991). (Erról a feltevésról részletesen lásd az 1.3.2. részt.) A viselkedés elórejelzésének pontossága annak is függvénye, hogy az észlelt viselkedési kontroll menynyire áll közel a tényleges viselkedési kontrollhoz.

A viselkedés magyarázata mellett az elmélet másik - és Ajzen (2011) szerint fontosabb - célja a szándék előrejelzése. A tervezett viselkedés elmélete szerint a szándékot három tényezó határozza meg: a viselkedés iránti attitúd, a viselkedés végrehajtására vonatkozó észlelt társas nyomás és az észlelt viselkedési kontroll.

Az attitúd fogalma ebben az elméleti keretben az adott viselkedéssel kapcsolatos pozitív vagy negatív véleményt jelenti (Ajzen, 1991). A fogalommal kapcsolatos elméleti felvetésekról részletesen lásd késóbb (1.3.3. rész). Az 1960-as évekig összegyúlt szociálpszichológiai kutatási eredmények azt mutatták, hogy az attitúd alapján nem lehet a viselkedést magyarázni vagy bejósolni (Ajzen \& Fishbein, 2005; Kim \& Hunter, 1993; Wicker, 1969). Ennek a sikertelenségnek az egyik oka az volt, hogy eltért a két té- 
nyezô mérési szintje: általános attitúd hatását vizsgálták egy konkrét viselkedésre (Ajzen \& Fishbein, 2005; Kim \& Hunter, 1993). Az aggregáció elve szerint (Ajzen \& Fishbein, 2005), ha általános attitúd összefüggéseit szeretnénk vizsgálni, akkor az adott attitúdnek megfelelő viselkedések széles skáláját szükséges mérni, és ebben az esetben várható, hogy az attitúd elóre jelzi a viselkedéseket. A tervezett viselkedés elmélete alkalmazása során is fontos a megfelelés vagy kompatibilitás elvét követni, azaz ugyanazon a szinten mérni mind a viselkedést, mind az attitúdöt (Ajzen, 2012; Ajzen \& Fishbein, 2005; Francis és mtsai, 2004).

A viselkedéssel kapcsolatos releváns kontextuális tényezóket az attitúdnél és a viselkedésnél is megadjuk (Francis és mtsai, 2004): definiáljuk a viselkedés célját, a cselekvést, a kontextust és az idót, akár nagyon specifikus, akár általánosabb szintról van szó (Ajzen \& Fishbein, 2005). Például, ha a mérni kívánt viselkedés a rendszeres testmozgás, akkor a kutatás tervezése során elóször is meghatározzuk, hogy mit értünk rendszeres testmozgás alatt (pl. legalább heti háromszor testmozgást végez alkalmanként legalább 30 perc időtartamban), és az erre vonatkozó attitúdöt mérjük fel (pl. „Testmozgás végzése legalább heti háromszor, alkalmanként legalább 30 perc idótartamban 1 egészséges ... 7 egészségtelen a számomra"). A mért viselkedést is ennek megfelelóen definiáljuk („Milyen gyakran végzett testmozgást az elmúlt ... napban legalább 30 perc idótartamban?"). Ha nem ezt tesszük, hanem általában a testmozgással kapcsolatban kérdezzük a résztvevőket (, ${ }_{(}$A testmozgás 1 egészséges ... 7 egészségtelen a számomra"), akkor az attitúd és a viselkedés mérési szintje nem fog egymásnak megfelelni. A fenti meghatározás esetében természetesen a testmozgás definíciójának tisztázására is szükség van. A megfelelés vagy kompatibilitás elvét nemcsak az attitúd és a viselkedés esetében alkalmazzuk, hanem az elmélet minden elemét ennek megfelelóen határozzuk meg. Az attitúd és a viselkedés mérési szintjének kompatibilitása valóban növeli az attitúdviselkedés kapcsolat erősségét (Kim \& Hunter, 1993).

A szándékot meghatározó második tényezó a szubjektív norma, ami lényegében a személyre ható „észlelt társas nyomás az adott viselkedés megvalósítására vagy meg nem valósítására” (Ajzen, 1991). A fogalom változott az idók során. Eredeti megfogalmazásában az észlelt társas nyomás azt jelentette, hogy a személy hogy érzi, egy adott cselekvés végrehajtását (vagy éppen a végre nem hajtását) elvárják-e tóle mások; késóbb ezt az eredeti fogalmat elóíró (injunctive) normának nevezték (Manning, 2009). A szubjektív norma másik típusává a leíró (descriptive) norma vált, ami azt fejezi ki, hogy a személy számára fontos emberek hogyan cselekszenek (vagy feltételezetten hogyan cselekszenek) a személy környezetében (Ajzen, 2012; Manning, 2009). 
A harmadik elem, ami a szándékot közvetlenül befolyásolja, a már említett észlelt viselkedési kontroll. Mindhárom, a szándékot befolyásoló tényező mögött bizonyos hiedelmek állnak, ezek tehát közvetetten befolyásolják a szándékot, így végső soron magát a viselkedést is. A viselkedés várható kimeneteire vonatkozó hiedelmek és e kimenetek értékelése alakítja az attitúdöket (az attitúd expektancia-érték modellje; Ajzen, 1991). A szubjektív értékelés a hiedelem erősségének megfelelő mértékben járul hozzá az attitúd kialakulásához (Ajzen, 1991), így a viselkedési hiedelmeket a viselkedés különböző következményei erốsségének és e következmények értékelésének a szorzataként kapjuk meg (Francis és mtsai, 2004). Mindegyik viselkedéssel kapcsolatban természetesen több hiedelem is létezik, ezek hozzáférhetősége is változhat; az éppen hozzáférhetô hiedelmek összege alakítja ki végül a viselkedéssel kapcsolatos attitúdöket (Ajzen, 1991).

A szubjektív normát, tehát az észlelt társas nyomást az alakítja ki, hogy a személy mit gondol arról, hogy a számára fontos konkrét személyek (pl. a házastársa, orvosa stb.) mennyire várják el tóle az adott viselkedést, és hogy ô mennyire szeretne együttmúködni ezekkel az elvárásokkal. A normatív hiedelem tehát az adott viselkedésre vonatkozó elvárás eróssége és az együttmúködési hajlandóság szorzata (Ajzen, 1991; Francis és mtsai, 2004). Természetesen itt is igaz az, hogy több társas hatás, több elvárás éri a személyt, és ezek összessége alakítja ki a szubjektív normát. Fontos ugyanakkor, hogy a hiedelmek konkrét személyek konkrét cselekvésre vonatkozó elvárásaira vonatkoznak, melyek eredójeként általános észlelt társas nyomás alakul ki. Utóbbit fejezi ki a szubjektív norma, pontosabban a szubjektív normának az elóíró norma része (Manning, 2009). A szubjektív norma másik eleme, a leíró norma, mások megfigyelt vagy feltételezett viselkedését jelenti (Manning, 2009), azzal kapcsolatos elemet nem tartalmaz a normatív hiedelmek fogalma.

Az észlelt viselkedési kontrollt a kontrollhiedelmek alakítják. A kontrollhiedelmek a cselekvés megvalósítását elôsegító vagy gátló tényezók, valamint azok észlelt erőssége szorzataként alakulnak ki (Ajzen, 1991; Francis és mtsai, 2004). A viselkedési, a normatív és a kontrollhiedelmekkel kapcsolatban egyaránt elmondható, hogy többféle, akár egymásnak részben ellentmondó hiedelem létezhet ugyanazzal a viselkedéssel kapcsolatban. Ezek a hiedelmek nem feltétlenül racionálisak és nem feltétlenül tükrözik hûen a valóságot (Ajzen, 2011); ezek a személy szubjektív hiedelmei, melyeket nagyon sok társadalmi, kulturális és személyes tényezó befolyásol (Ajzen \& Fishbein, 2005; a hiedelmeket befolyásoló tényezóket lásd az 1. ábrán). E hiedelmek fontos jellemzóje továbbá, hogy nem állandó tényezônek érdemes óket elképzelni, hanem folyamatosan változik a hozzá- 
férhetôségük; az aktuálisan hozzáférhető hiedelmektól függ az attitúd, szubjektív norma és az észlelt viselkedési kontroll, és a belólük kialakuló szándék is a viselkedés végrehajtására. Ez azt is jelenti, hogy a hiedelmek hozzáférhetôségének változtatásával befolyásolhatóak ezek a tényezók, így módosítható a viselkedés megjelenésének valószínúsége.

A tervezett viselkedés elmélete elsősorban az emberi döntéshozatal és viselkedés kontrollált, célirányos és tudatos aspektusait hangsúlyozza (Ajzen, 2011). A hiedelmek azonban, mint láttuk, gyakran korántsem racionális alapokon nyugszanak, bár hozzáférhetôségük befolyásolható tudatosan. Azzal, hogy a viselkedési, normatív és kontrollhiedelmek a modellben szerepelnek, a modell részeivé váltak a viselkedést befolyásoló kevésbé tudatos elemek is. Ezek mérése is nagyobb körültekintést igényel: a hiedelmeket akkor tudjuk viszonylag pontosan mérni, ha elózetes feltáró tanulmányokat végzünk (Ajzen, 1991; Francis és mtsai, 2004, részletesen lásd késóbb, az 1.2.1. részben).

A tervezett viselkedés elméletével kapcsolatban egyébként gyakori kritika, hogy túl „racionális”, nem veszi megfelelő mértékben figyelembe az emberi viselkedést befolyásoló egyéb (érzelmi és nem tudatos kognitív) tényezóket (Ajzen, 2011). Az elsôsorban nem tudatos irányítás alatt álló viselkedések egy típusa a sokszori ismétlődés által szokássá vált viselkedések, melyek esetében a viselkedés sokszor automatizálódik, tehát nem igényel tudatos döntést a végrehajtása. Ajzen (2012) szerint a modell ezekre a cselekvésekre is alkalmazható; a szokásoknál implicit szándék határozza meg a viselkedést, és a modell többi eleme is kevésbé tudatos, mint a ritkább vagy kiemelkedóbb cselekvések esetében. A szokások kérdésköre azonban átvezet a korábbi viselkedés szerepének kérdéséhez, részletesen ott tárgyalom ezt a témát (lásd a 2. részben). Ez elótt azonban a tervezett viselkedés elméletével kapcsolatos kutatási eredményeket, majd az elmélettel kapcsolatos fóbb szakmai vitákat foglalom össze.

\subsection{A tervezett viselkedés elméletével kapcsolatos empirikus kutatások eredményei}

\subsubsection{Metaelemzések: a modell eredményessége a viselkedés és a szándék elörejelzésében}

Az elmélet tesztelésére végzett kutatások eredményéból készült metaelemzések azt mutatják, hogy az elméletet alapvetóen alátámasztják az empirikus adatok (Ajzen, 1991; Armitage \& Conner, 2001; Blue, 1995; Godin \& Kok, 1996; Hagger, Chatzisarantis, \& Biddle, 2002; Hausenblas, Carron, 
\& Mack, 1997; McEachan, Conner, Taylor, \& Lawton, 2011), bár a modell predikciós ereje több tényezótól is függ (McEachan és mtsai, 2011), ${ }^{2}$ és öszszességében alacsonynak tekinthetó. A metaelemzések részletes eredményei az 1. táblázatban láthatóak.

A metaelemzések többsége szerint a modell átlagosan a szándék varianciájának 39-44\%-át magyarázza, a viselkedés varianciájának pedig 19-34\%-át ${ }^{3}$ (Armitage \& Conner, 2001; Godin \& Kok, 1996; Hagger és mtsai, 2002; McEachan és mtsai, 2011). Lényegesen alacsonyabb értékeket kapott a serdülókori dohányzást vizsgáló tanulmányokról készített metaelemzés: ebben az esetben a viselkedés és a szándék varianciájának 12, illetve $13 \%$-át magyarázta a modell (Topa \& Moriano, 2010).

A viselkedés mérési módja is számít: a viselkedés önbeszámolós mérése esetén a viselkedés varianciájának nagyobb arányát magyarázza a modell,

1. táblázat. A tervezett viselkedés elmélete elemeinek kapcsolata egymással a metaelemzések adatai szerint

\begin{tabular}{|c|c|c|c|c|c|c|}
\hline Metaelemzés & $\begin{array}{c}\text { Godin \& } \\
\text { Kok, } \\
1996 *\end{array}$ & $\begin{array}{c}\text { Armitage } \\
\& \\
\text { Conner, } \\
2001\end{array}$ & $\begin{array}{c}\text { McEachan } \\
\text { és mtsai, } \\
\text { 2011* }\end{array}$ & $\begin{array}{c}\text { Hagger } \\
\text { és mtsai, } \\
2002\end{array}$ & $\begin{array}{c}\text { Topa \& } \\
\text { Moriano, } \\
2010\end{array}$ & $\begin{array}{c}\text { Symons } \\
\text { Downs \& } \\
\text { Hausen- } \\
\text { blas, 2005** }\end{array}$ \\
\hline $\begin{array}{l}\text { Vizsgált } \\
\text { viselkedés }\end{array}$ & $\begin{array}{l}\text { egészség- } \\
\text { viselke- } \\
\text { dések }\end{array}$ & bármilyen & $\begin{array}{l}\text { egészség- } \\
\text { viselke- } \\
\text { dések }\end{array}$ & $\begin{array}{l}\text { test- } \\
\text { mozgás }\end{array}$ & $\begin{array}{l}\text { dohány- } \\
\text { zás ser- } \\
\text { dülóknél }\end{array}$ & testmozgás \\
\hline $\begin{array}{l}\text { Az elemzett } \\
\text { vizsgálatok } \\
\text { számaa }\end{array}$ & $56 / 58$ & $161 / 185$ & $206 / 237$ & $72 / 79$ & $27 / 35$ & 47 \\
\hline $\begin{array}{l}\text { A viselkedés } \\
\text { magyarázott } \\
\text { aránya (\%) }\end{array}$ & $\begin{array}{c}34,0 \\
(15,6-42,3)\end{array}$ & 27 & $\begin{array}{c}19,3 \\
(13,8-23,9)\end{array}$ & 27,41 & $12^{\mathrm{e}}$ & \\
\hline $\begin{array}{l}\text { A szándék } \\
\text { magyarázott } \\
\text { aránya }(\%)\end{array}$ & $\begin{array}{c}40,9 \\
(32,0-46,8)\end{array}$ & 39 & $\begin{array}{c}44,3 \\
(36,6-51,3)\end{array}$ & 44,5 & $13^{e}$ & \\
\hline $\begin{array}{l}\text { Szándék - } \\
\text { viselkedés }\end{array}$ & $\begin{array}{c}0,46^{\mathrm{b}} \\
(0,35-0,56)\end{array}$ & $47^{c}$ & $\begin{array}{c}4^{4} 3^{\mathrm{d}} \\
(0,37-0,48)\end{array}$ &, $51^{\mathrm{d}}$ &, $30^{\mathrm{f}}$ & \\
\hline $\begin{array}{l}\text { Észlelt viselke- } \\
\text { dési kontroll - } \\
\text { viselkedés }\end{array}$ & $\begin{array}{c}0,39^{\mathrm{b}} \\
(0,29-0,51)\end{array}$ & $37^{c}$ & $\begin{array}{c}, 31^{\mathrm{d}} \\
(0,22-0,35)\end{array}$ & $39^{\mathrm{d}}$ &,$- 20^{f}$ & \\
\hline $\begin{array}{l}\text { Attitúd - } \\
\text { szándék }\end{array}$ & $\begin{array}{c}0,46^{\mathrm{b}} \\
(0,26-0,53)\end{array}$ &, $49^{c}$ & $\begin{array}{c}, 57^{\mathrm{d}} \\
(0,52-0,62)\end{array}$ & $60^{\mathrm{d}}$ &, $16^{\mathrm{f}}$ & \\
\hline
\end{tabular}

${ }^{2}$ McEachan és munkatársai (2011) a viselkedéstípust, az utánkövetés idótartamát, a minta életkorát és a viselkedés mérési módját vizsgálták. Ezek közül a viselkedéstípussal és a viselkedés mérési módjával kapcsolatos eredményeket ismertetem a szövegben.

${ }^{3}$ A tanulmány szövegében minden esetben egész számra kerekítve közlöm a megmagyarázott variancia tartományát. A pontos adatok a vonatkozó táblázatokban találhatóak. 
1. táblázat folytatása

\begin{tabular}{|c|c|c|c|c|c|c|}
\hline Metaelemzés & $\begin{array}{c}\text { Godin \& } \\
\text { Kok, } \\
1996^{*}\end{array}$ & $\begin{array}{l}\text { Armitage } \\
\& \\
\text { Conner, } \\
2001 \\
\end{array}$ & $\begin{array}{c}\text { McEachan } \\
\text { és mtsai, } \\
2011^{*}\end{array}$ & $\begin{array}{c}\text { Hagger } \\
\text { és mtsai, } \\
2002\end{array}$ & $\begin{array}{c}\text { Topa \& } \\
\text { Moriano, } \\
2010\end{array}$ & $\begin{array}{c}\text { Symons } \\
\text { Downs \& } \\
\text { Hausen- } \\
\text { blas, 2005** }\end{array}$ \\
\hline $\begin{array}{l}\text { Szubjektív } \\
\text { norma - szándék }\end{array}$ & $\begin{array}{c}0,34^{\mathrm{b}} \\
(0,16-0,48)\end{array}$ &, $34^{c}$ & $\begin{array}{c}, 40^{\mathrm{d}} \\
(0,34-0,56)\end{array}$ &, $32^{\mathrm{d}}$ & $20^{f}$ & \\
\hline $\begin{array}{l}\text { Észlelt viselke- } \\
\text { dési kontroll - } \\
\text { szándék }\end{array}$ & $\begin{array}{c}0,46^{\mathrm{b}} \\
(0,32-0,67)\end{array}$ & $43^{c}$ & $\begin{array}{c}, 54^{\mathrm{d}} \\
(0,45-0,55)\end{array}$ &, $57^{\mathrm{d}}$ &,$- 24^{\mathrm{f}}$ & \\
\hline $\begin{array}{l}\text { Viselkedési hie- } \\
\text { delmek - attitúd }\end{array}$ & &, $50^{c}$ & $43^{\mathrm{d}}$ & & & $\begin{array}{c}54,2 \% \\
(43-59 \%)^{g}\end{array}$ \\
\hline $\begin{array}{l}\text { Normatív hie- } \\
\text { delmek - szub- } \\
\text { jektív norma }\end{array}$ & &, $50^{c}$ &, $53^{\mathrm{d}}$ & & & $\begin{array}{c}55,8 \% \\
(41-68 \%)^{g}\end{array}$ \\
\hline $\begin{array}{l}\text { Kontrollhiedel- } \\
\text { mek - észlelt vi- } \\
\text { selkedési kontroll }\end{array}$ & &, $52^{\mathrm{c}}$ & $41^{\mathrm{d}}$ & & & $\begin{array}{c}33,7 \% \\
(5-58 \%)^{g}\end{array}$ \\
\hline
\end{tabular}

Megjegyzés:

* A tanulmány az egyes egészségviselkedésekre vonatkozó adatokat is közöl, ezért az átlagos korreláció mellett az egyes egészségviselkedések esetében kapott legalacsonyabb és legmagasabb értéket is közlöm. Az adatokat részletesen lásd a 2. táblázatban.

** A tanulmány csak a testmozgással kapcsolatos viselkedéses, normatív és kontrollhiedelmek kapcsolatát vizsgálta olyan tanulmányokban, melyekben végeztek elózetes tanulmányt (elicitation study).

a Az elsố szám az elemzett tanulmányok számát, a második az elemzett adatsorok számát jelenti.

b Átlagos korreláció.

${ }^{\mathrm{c}}$ Mintamérettel súlyozott korreláció.

d A mintavétel hibájával és a mérési hibával korrigált korreláció.

e A tanulmány szövege szerint a viselkedés magyarázott aránya $12 \%$, a szándéké pedig 13\% (Topa \& Moriano, 2010, 28. o.). A szöveghez tartozó ábrán (uo., 30. o.) ezek a számok fordítva szerepelnek.

f Súlyozott korreláció.

g A hiedelem által az adott konstruktum varianciájának megmagyarázott aránya (zárójelben: a megmagyarázott variancia tartománya).

mint objektív mérés (megfigyelt viselkedés) esetében. Armitage és Conner (2001) metaelemzése szerint a viselkedés megfigyeléses mérésénél a megfigyelt viselkedés varianciájának $20 \%$-át magyarázza a modell, ${ }^{4}$ ezzel szemben a viselkedés önbeszámolós mérése esetében a megmagyarázott variancia 31\%. A kettô közötti különbség szignifikáns, a szerzók következtetése az, hogy ennek ellenére a tervezett viselkedés elmélete a tényleges viselkedés lényeges arányát megmagyarázza (Armitage \& Conner, 2001).

${ }^{4}$ A tanulmány absztraktjában $21 \%$ szerepel, azonban ez valószínúleg elírás, mivel ott is 11\% különbségról beszélnek a két mérési mód esetében. 
McEachan és munkatársai (2011) a testmozgás esetében kaptak hasonló, de ezeknél alacsonyabb értékeket: az önbeszámolós viselkedés varianciájának 26\%-át, míg a megfigyelt viselkedés varianciájának $12 \%$-át magyarázta a modell. A viselkedés kétféle mérése közötti nagy különbség miatt egyrészt a kutatási eredményeket érdemes óvatosabban interpretálni, hiszen a pszichológiai kutatásokban a viselkedés mérése nagyon gyakran önbeszámolós módszerrel történik, másrészt viszont érdemes a viselkedés objektív mérésére törekedni.

Az elmélet központi feltételezése, hogy a viselkedésre vonatkozó szándék meghatározza a viselkedést. A szándék és a viselkedés átlagos korrelációja 0,30 és 0,51 között változik (Armitage \& Conner, 2001; Godin \& Kok, 1996; Hagger és mtsai, 2002; McEachan és mtsai, 2011; Topa \& Moriano, 2010), a szándék átlagosan a viselkedés $28 \%$-át magyarázza (Sheeran, 2002). McEachan és munkatársai (2011) elemzése szerint a viselkedés két közvetlen elórejelzóje közül a szándék az erósebb prediktor $(\beta=0,37)$, az észlelt viselkedési kontroll kevesebb, mint harmadannyi magyarázó eróvel bír $(\beta=0,11)$. A korábbi viselkedés bevonásával azonban jelentôsen csökkent mindkét elem magyarázó ereje (a szándék esetében a $\beta$-együttható 0,22-ra, az észlelt viselkedési kontroll esetében pedig 0,07-ra csökkent). A korábbi viselkedés hasonló hatását mutatta ki Hagger és munkatársai (2002) tanulmánya is. (A korábbi viselkedés szerepéról részletesen lásd késóbb, a 2. részben.)

A szándék és a viselkedés között akkor feltételezhetünk ok-okozati kapcsolatot, ha bizonyítást nyer, hogy a szándék megváltoztatásával a viselkedés is változik. A szándékot random elrendezéssel változtató intervenciókból készített metaelemzés szerint (Webb \& Sheeran, 2006) az intervenciók átlagos hatásmérete $\mathrm{d}=0,66$ volt $(95 \% \mathrm{CI}=0,51-0,82)$, az ebból eredố viselkedésváltozás átlagos hatásmérete pedig $\mathrm{d}=0,36(95 \%$ $\mathrm{CI}=0,22-0,50)$. Tehát a szándék közepes-nagy erôsségú változásával az adott viselkedés kis-közepes mértékben változik meg. Azoknál az intervencióknál, ahol a szándék nem változott lényegesen $(\mathrm{d}=0,007,95 \% \mathrm{CI}=$ $0,00-0,13)$, a viselkedésben kismértékú változás következett be $(\mathrm{d}=0,20$, $95 \%$ CI = 0,08-0,32). Lehet tehát viselkedéses változás akkor is, ha a szándék nem változik jelentôsen, de lényegesen kisebb, mint amikor a szándékban érnek el változást.

A szándékot elóre jelzó tényezók közül többnyire az attitúd kapcsolódik legerósebben a szándékhoz. Armitage és Conner (2001) adatai szerint a szándék varianciájának 24\%-át magyarázza az attitúd (0,49-es korreláció); Hagger és munkatársai (2002) eredményei szerint még erősebb a kapcsolat a kettố között: az attitúd és a szándék korrigált korrelációja 0,60. McEachan és munkatársai (2011) szerint is az attitúd legerósebb prediktor $(\beta=0,35)$. 
Az észlelt viselkedési kontroll csaknem ugyanolyan erôsen kapcsolódik a szándékhoz, mint az attitúd, mind egészségviselkedések (McEachan és mtsai, 2011), mind a testmozgás esetében (Blue, 1995; Hagger és mtsai, 2002). McEachan és munkatársai (2011) szerint a prediktív ereje $\beta=0,34$. A leggyengébb a szubjektív norma és a szándék kapcsolata egy sokféle viselkedést összegzó metaelemzés adatai (Armitage \& Conner, 2001: $R^{2}$ $=0,12)$, valamint az egészségviselkedésekkel kapcsolatos metaelemzés (McEachan és mtsai, 2011: $\beta=0,15$ ), továbbá a testmozgásra vonatkozó vizsgálatokat összegző metaelemzés szerint is (Hagger és mtsai, 2002: $\mathrm{r}=$ $0,32)$. Ennek részben lehet módszertani oka: a szubjektív normát gyakran egy tétellel mérik csak, pedig többtételes mérés esetében kicsit nagyobb az elốre jelzố szerepe (Armitage \& Conner, 2001). Valószínúbb azonban az a magyarázat, hogy bizonyos cselekvések esetében (pl. testmozgás vagy étkezés) a társas nyomás kevésbé fontos, mint akár a személy attitúdje az adott cselekvéssel kapcsolatban, akár az észlelt viselkedési kontroll. A serdülókori dohányzás esetében a fentitól markánsan eltéró mintát mutatott Topa és Moriano (2010) metaelemzése, melyben serdülókkel és egyetemistákkal végzett keresztmetszeti vizsgálatok eredményeit összegezték: itt az észlelt viselkedési kontroll és a szubjektív norma mutatta a legerősebb kapcsolatot a szándékkal, az attitúd pedig a leggyengébbet; ennek az eltérésnek az oka egyaránt lehetett a vizsgált viselkedés jellege, valamint a minta életkora is.

A modell szerint az attitúdök, a szubjektív norma és az észlelt viselkedési kontroll a megfelelő hozzáférhető hiedelmekból származnak. A hiedelmek és a belólük származónak feltételezett konstruktum között azonban gyakran csak viszonylag gyenge korrelációt találnak; Ajzen (1991) ennek egyik lehetséges okának azt tartotta, hogy a hiedelemkérdések megválaszolása több figyelmet igényel, míg a globális kérdésekre inkább automatikus módon adunk választ. A gyengébb korreláció másik oka az lehet, hogy a modell esetleg nem teljesen írja le a szerepet játszó folyamatokat. Azóta több metaelemzés is vizsgálta a hiedelmek és a belólük származtatott tényezó kapcsolatát (a részletes adatokat lásd az 1. táblázatban).

Armitage és Conner (2001) szerint az attitúdök és a viselkedéses hiedelmek, illetve a szubjektív norma és a normatív hiedelmek korrelációja egyaránt 0,50; a hiedelmek így az attitúd, illetve a szubjektív norma $25 \%$-át magyarázzák. McEachan és munkatársai (2011) az attitúd és mögöttes hiedelme esetében valamennyivel alacsonyabb, 0,43-as korrelációt találtak, míg a szubjektív norma és hiedelme között kicsit magasabbat $(0,53)$. Elózetes feltáró tanulmány (elicitation study) esetében jóval erősebb kapcsolatok találhatók. A viselkedéses hiedelmek az attitúd varianciájának 54\%-át magyarázzák (43-59\% között), ez nagy hatásméretet jelent (átlagos hatásméret 
1,36, szórás $0,06, \mathrm{n}=21$ ), a normatív hiedelmek pedig ebben az esetben a szubjektív norma varianciájának 59\%-át magyarázzák (tartomány: 41-68\% között); a hatásméret nagy $(1,20$, szórás 0,06, n = 19) (Symons Downs \& Hausenblas, 2005). Mindez azt jelenti, hogy - Ajzen eredeti koncepciója szerint (Ajzen, 1991; Francis és mtsai, 2004) - érdemes elózetes feltáró tanulmányokat végezni a tervezett mintának megfeleló csoportban.

Az észlelt viselkedési kontroll és a kontrollhiedelmek kapcsolatát vizsgáló eredmények az elózóeknél változatosabbak: a kettó korrelációja 0,41 és 0,57 közötti (Armitage \& Conner, 2001; Gagné \& Godin, 2000; McEachan és mtsai, 2011). Elózetes feltáró tanulmányok esetében nagy hatásméretú a kettő kapcsolata: átlagos hatásméret 1,04, szórás 0,05, n = 12 (Symons Downs \& Hausenblas, 2005). A kontrollhiedelmek az észlelt viselkedési kontroll varianciájának átlagosan 34\%-át magyarázták, a megmagyarázott variancia terjedelme azonban nagy, 5-58\% közötti. Ez azt mutatja, hogy az észlelt viselkedési kontroll elórejelzése vagy magyarázata a legnehezebben megoldható.

Összességében a metaelemzések közepes-nagy hatásméretet mutattak ki a szándékot előrejelzô három tényezó és a mögöttes hiedelmeik kapcsolatáról, amelyek azonban változó mértékúek. Symons Downs és Hausenblas (2005) metaelemzése rendre nagyobb kapcsolatot talált, mint a többi meta-

2. táblázat. A tervezett viselkedés elméletének magyarázó ereje, valamint az elmélet egyes elemeinek kapcsolata az egyes egészségviselkedések esetében

\begin{tabular}{|l|c|c|c|c|c|c|c|}
\hline & $\begin{array}{c}\text { Viselke- } \\
\text { dés ma- } \\
\text { gyará- } \\
\text { zott ará- } \\
\text { nya (\%) }\end{array}$ & $\begin{array}{c}\text { Viselke- } \\
\text { dés ma- } \\
\text { gyará- } \\
\text { zott ará- } \\
\text { nya }(\%)^{* *}\end{array}$ & $\begin{array}{c}\text { Szándék } \\
- \text { visel- } \\
\text { kedés } \\
(\rho)^{* *}\end{array}$ & $\begin{array}{c}\text { ÉVK - } \\
\text { viselke- } \\
\text { dés }(\rho)^{* * *}\end{array}$ & $\begin{array}{c}\text { Attitúd } \\
- \text { szán- } \\
\text { dék }(\rho)^{* *}\end{array}$ & $\begin{array}{c}\text { Szubjek- } \\
\text { tív } \\
\text { norma - } \\
\text { szándék } \\
(\rho)^{* * *}\end{array}$ & $\begin{array}{c}\text { ÉVK - } \\
\text { szándék } \\
(\rho)^{* *}\end{array}$ \\
\hline Testmozgás & 36,3 & 23,9 & 0,48 & 0,34 & 0,60 & 0,38 & 0,55 \\
\hline Étkezés & 25,0 & 21,2 & 0,44 & 0,35 & 0,62 & 0,43 & 0,53 \\
\hline Absztinencia* & n. a. & 15,3 & 0,37 & 0,28 & 0,52 & 0,34 & 0,45 \\
\hline Betegségdetekció & 15,6 & 14,5 & 0,38 & 0,22 & 0,52 & 0,35 & 0,51 \\
\hline Biztonságos szex & 42,3 & 13,8 & 0,37 & 0,22 & 0,59 & 0,56 & 0,49 \\
\hline Rizikóviselkedés & 40,7 & 14,8 & 0,38 & 0,24 & 0,52 & 0,45 & 0,49 \\
\hline
\end{tabular}

Megjegyzés:

* Godin és Kok (1996) eredményei.

** McEachan és mtsai (2011) eredményei.

*** Az absztinencia körébe sorolt 13 tanulmányból 12 a dohányzástól, egy pedig a mértéktelen alkoholfogyasztástól való tartózkodással foglalkozott.

$\rho$ : Átlagos súlyozott, a mintavételi és mérési hibával korrigált korreláció.

ÉVK: észlelt viselkedési kontroll. 
elemzés. Jobban előrejelezhetók tehát a szándék prediktorai, ha az elmélet útmutatásának megfelelóen az adott hiedelmekról előzetes feltáró tanulmányt is folytatnak a kutatók a vizsgált populációnak megfeleló mintán.

\subsubsection{A tervezett viselkedés elmélete az egyes egészségviselkedések esetében}

A tervezett viselkedés elméletének magyarázó ereje, valamint elemei kapcsolatának mintázata és a kapcsolatok erôssége eltér a különbözó egészségviselkedések esetében. Godin és Kok (1996) korai metaelemzése szerint a viselkedés megmagyarázott varianciája 16\% és $42 \%$ között változott az egyes viselkedéseknél; McEachan és munkatársai (2011) ennél alacsonyabb értékeket kaptak (14-24\%) (részletes adatok a 2. táblázatban). A két metaelemzés eredményei a testmozgás és az étkezés, valamint a betegségdetekció esetében összhangban állnak: az első kettố a viszonylag jól magyarázott viselkedések közé tartozik, a betegségdetekciót (pl. emlóvizsgálat vagy szû́réseken való megjelenés) pedig mindkét elemzés szerint gyengén magyarázza a modell. A biztonságos szexszel és a rizikóviselkedésekkel kapcsolatban viszont jelentősen eltér a két metaelemzés eredménye: Godin és Kok (1996) eredményei szerint ezeknél a legjobb a modell magyarázó ereje, McEachan és munkatársai (2011) viszont ezeknél kapták a leggyengébb eredményeket. Utóbbi eredményt támasztja alá Topa és Moriano (2010) metaelemzése is: serdülók és egyetemisták dohányzási szokásaival kapcsolatban végzett keresztmetszeti kutatások esetében a viselkedés magyarázott aránya mindössze 12 \% volt. Ennek alapján valószínúbbnek túnik, hogy a rizikóviselkedések esetében alacsony a modell magyarázó ereje.

\subsection{A tervezett viselkedés elméletének vitatott pontjai}

\subsubsection{Az észlelt viselkedési kontrollal kapcsolatos vitatott kérdések}

A modellel kapcsolatos egyik legvitatottabb kérdés az észlelt viselkedési kontroll meghatározása, lehetséges összetevói, valamint a fogalom kapcsolata más pszichológiai fogalmakkal. A terminológiával kapcsolatos nehézséghez hozzájárul, hogy ugyanazokat az elnevezéseket más-más meghatározással használják az egyes szerzók, illetve ugyanaz a fogalom más elnevezést kap az egyes szerzóknél. Az észlelt viselkedési kontrollal kapcsolatban két kérdést tárgyalok a következókben: az énhatékonyság és a viselkedés észlelt nehézségének témáját. Mindkét kérdés kapcsolatos az észlelt viselkedési kontroll fogalmának és összetevóinek kérdésével.

Fentiekben láttuk, hogy Ajzen (2002a) az észlelt viselkedési kontroll fogalmát hierarchikus felépítésúnek képzelte és két elemre bontotta: az énhatékonyságra (amit azonosnak tekintett a viselkedés végrehajtásának 
észlelt nehézségével) és a viselkedés kontrollálhatóságára (mennyire függ a személytól a viselkedés végrehajtása). Korábbi definíciói azonban nem voltak ennyire egyértelmúek. Ajzen és Madden (1986, 457. o.) szerint az észlelt viselkedési kontroll „a személy hiedelme arról, hogy a viselkedés végrehajtása valószínúleg mennyire lesz könnyú vagy nehéz". Ajzen 1991-es tanulmánya is hasonlóan, tehát a viselkedés észlelt nehézségeként definiálja a fogalmat (Ajzen, 1991), emellett azonban megjegyzi, hogy az észlelt viselkedési kontroll Bandura észlelt énhatékonyság-fogalmához (Bandura, 1982, 1992) áll legközelebb, ebból a szempontból tehát azt a meggyózôdést/önbizalmat, magabiztosságot jelenti (confidence), hogy a személy képes a viselkedés végrehajtására. Késóbb ezt a két dolgot (a viselkedés észlelt nehézségét és az énhatékonyságot) kezelte szinonimaként, énhatékonyság elnevezéssel.

Az „észlelt viselkedési kontroll vagy énhatékonyság” (Ajzen, 1998, 737. o.) Bandura és munkatársai kutatásai alapján került a tervezett viselkedés elméletébe; a modell ezzel „az énhatékonyság vagy észlelt viselkedési kontroll fogalmát a hiedelmek, attitúdök, szándékok és viselkedés közötti kapcsolatok általánosabb keretébe helyezi" (Ajzen, 1991, 184. o.) Ezek a megfogalmazások arra utalnak, hogy Ajzen az énhatékonyság és az észlelt viselkedési kontroll fogalmát szinonimának tartotta, elméletének újdonságának pedig a fogalom tágabb keretbe helyezését tekintette.

A kutatási eredmények szerint az énhatékonyság többnyire a szándékkal, az észlelt viselkedési kontroll pedig a viselkedéssel áll kapcsolatban (Armitage \& Conner, 2001; Terry \& O'Leary, 1995). Testmozgással kapcsolatos tanulmányok metaelemzése során Hagger és munkatársai (2002) az eredeti modell mellett az énhatékonyságot is tartalmazó modellt is tesztelték. Az énhatékonyság az észlelt viselkedési kontrolltól függetlenül előre jelezte a szándékot $(\beta=0,28)$, illetve a viselkedést $(\beta=0,15)$. Az így kiegészített modell magyarázó ereje nôtt: az eredeti modell a viselkedés varianciájának 27,4\%-át, míg az énhatékonysággal kiegészített modell 29,1\%-át magyarázta (Hagger és mtsai, 2002). Ezek az eredmények tehát azt mutatják, hogy az észlelt viselkedési kontroll nem tekinthetô az énhatékonyság szinonimájának.

Armitage és Conner metaelemzése (2001) az észlelt viselkedési kontroll háromféle mérését különböztette meg. Az észlelt viselkedési kontroll elnevezést azokra a mérési módokra alkalmazták, melyek a viselkedés végrehajtásának észlelt nehézségét/könnyúségét mérték; emellett az énhatékonyságot (az adott viselkedés végrehajtásának képességébe vetett bizalom) és a viselkedés végrehajtására vonatkozó észlelt kontrollt vették figyelembe; azt tehát, hogy a személy mennyire észleli kontrollja alatt állónak magát a helyzetet. Más szerzók a viselkedés felett észlelt kontroll mértéke és a vi- 
selkedés végrehajtásának észlelt nehézsége közti különbségre helyezték a hangsúlyt (Trafimow, Sheeran, Conner, \& Finlay, 2002).

Kraft, Rise, Sutton és Røysamb (2005) négy elemre bontotta az észlelt viselkedési kontrollt: észlelt nehézség, magabiztosság, észlelt kontroll és kontrollhely (mennyire gondolja, hogy teljesen tôle függ a viselkedés). Eredményeik szerint a kontrollhely-típusú tételek nem mutattak jelentôs összefüggést a szándékkal és az elmélet többi elemével, és azért is problémás a használatuk, mert a külsó-belsó kontroll dimenziója (Rotter, 1966) mentén történó attribúció felé irányíthatja a válaszadókat, ezért azt javasolják, hogy ezeket a tételeket érdemes kihagyni az észlelt viselkedési kontroll méréséból.

Az idézett definíciókból úgy túnik, három, egymással összefüggó, de egymástól megkülönböztethetó tényezóról van szó. Az énhatékonyság tekinthetó a viselkedés sikeres végrehajtására vonatkozó önbizalomnak; emellett fontos tényező a viselkedés észlelt nehézsége, illetve a viselkedés személyes kontrollálhatósága. Ebból a három elemból kialakulhat két faktor: az énhatékonyság és az észlelt nehézség alkotja az egyiket, a viselkedés kontrollálhatósága pedig a másikat (Kraft és mtsai, 2005). Ajzen késóbbi meghatározását (Ajzen, 2002a) ezzel nagyrészt alátámasztják az eredmények, azzal a különbséggel, hogy az észlelt nehézség és az énhatékonyság megkülönböztethetó egymástól. Az elmélethez tartozó kézikönyv is ezt a felosztást támogatja: az észlelt viselkedési kontroll két eleme a cselekvés kontrollálhatósága és az énhatékonyság; a viselkedés észlelt nehézsége pedig az énhatékonyság egy eleme (Francis és mtsai, 2004).

Armitage és Conner metaelemzése (2001) szerint az énhatékonyság és a viselkedés végrehajtásának észlelt nehézségeként definiált észlelt viselkedési kontroll erós kapcsolatban áll a szándékkal (a korreláció mindkettó esetében 0,44) és a viselkedéssel (az énhatékonyság-viselkedés korreláció: 0,35; az észlelt viselkedési kontroll-viselkedés korreláció: 0,40). Ehhez képest a viselkedés észlelt kontrollálhatósága gyengébben kapcsolódott a szándékhoz $(0,24)^{5}$ és a viselkedéshez is $(0,18)$.

Az énhatékonyság és az észlelt viselkedési kontroll összefüggései mellett a viselkedés észlelt nehézsége a másik kérdéses pont az észlelt viselkedési kontrollal kapcsolatban. Az előzó meghatározásokban láthattuk, hogy Ajzen (Ajzen, 1991; Ajzen \& Madden, 1986) eredeti megfogalmazásában ez volt az észlelt viselkedési kontroll meghatározása vagy annak egy eleme; Armitage és Conner metaelemzése (2001) is az észlelt nehézséggel definiálta az észlelt viselkedési kontrollt. Armitage és Conner (2001) kritikája

\footnotetext{
${ }^{5}$ A tanulmány szövegében 0,24 szerepel (Armitage \& Conner, 2001, 483. o.), a tanulmány 4. táblázatában 0,23 (uo., 484. o.).
} 
szerint azonban egy viselkedés észlelt nehézsége nem ad információt arról, hogy a nehézséget belső vagy külső tényezók jelentik-e. Ennek ellenére metaelemzésükben külön elemezhetônek tartották a viselkedés észlelt nehézségeként definiált észlelt viselkedési kontrollt, és az észlelt viselkedési kontroll elemei közül ez mutatta a legerôsebb összefüggést a szándékkal és a viselkedéssel. Trafimow és munkatársai (2002) 11 tanulmány összegzésével végzett metaelemzésében is hasonló eredményt kaptak. A viselkedés észlelt nehézsége és a kontroll, illetve a mögöttes hiedelmek is szétválaszthatók és külön manipulálhatók. Úgy tủnik tehát, hogy az észlelt nehézség fogalma informatív, annak ellenére, hogy nem ad információt arról, hogy az észlelt nehézséget belsô vagy külső tényezốk okozzák-e.

Ha viszont az észlelt nehézséget az észlelt viselkedési kontroll elemének tartjuk, akkor ez további elméleti kérdéseket vet fel. A viselkedés észlelt nehézsége ugyanis kapcsolódik az attitúd affektív komponenséhez is (Kraft és mtsai, 2005). Az észlelt viselkedési kontroll és az attitúd összefüggését Hagger és munkatársai (2002) metaelemzése is kimutatta: az indokolt cselekvés elméletének tesztelése után az észlelt viselkedési kontroll modellbe helyezésével a szándék-viselkedés kapcsolat erőssége nem változott, de az attitúd-szándék kapcsolat gyengült. Ezáltal a szándékot előre jelző tényezók között jön létre kapcsolat, ami kérdésessé teszi a modell elemeinek egyértelmú elkülöníthetőségét.

Az észlelt viselkedési kontroll szokásos mérési módjának tisztaságát kérdójelezte meg Rhodes és Courneya (2004) tanulmánya is. Ök nem értenek egyet azzal, hogy az észlelt viselkedési kontrollt utólag bontja a szakirodalom az énhatékonyság és a kontroll faktoraira. Szerintük az észlelt viselkedési kontroll magabiztosság és észlelt nehézség tételei motivációs tényezóket is tartalmaznak, és így a szándékkal függnek össze, ami azért problémás, mert az észlelt viselkedési kontroll a szándék prediktora, és így a prediktor és a függô változó között jön létre a mérési módszerból eredő kapcsolat. Ennek a mérési problémának a megoldására a szándék konstansan tartását javasolják. Felvetésük tesztelésére elvégeztek egy vizsgálatot, amelyben az észlelt viselkedési kontrollt kétféle tétellel mérték, a hagyományos módon (pl. „Mennyire biztos abban, hogy tudna testmozgást végezni az elkövetkezó két hétben?") és a motivációt állandóan tartó kifejezés hozzáadásával („,.., ha igazán akarná”). Faktorelemzést végeztek; a szándéktételek egy faktorra töltöttek, a kontrolltételek egy másik faktorra; a magabiztosság- és észlelt nehézség-tételek a hagyományos módon mérve mindkettóre, a motiváció állandónak tartásával viszont csak az észlelt viselkedési kontrollra. A konstruktumok tisztább mérése érdekében tehát érdemes az észlelt nehézséget és a magabiztosságot (énhatékonyságot) méró tételekhez hozzáadni a motiváció állandóságát biztosító kifejezést. 


\subsubsection{A viselkedés közvetlen prediktorainak hozzájárulása a viselkedés magyarázatához}

Ajzen (1991) eredeti feltételezése az volt, hogy az elsósorban akarati kontroll alatt álló viselkedések esetében a szándék mutatja a legerôsebb kapcsolatot a viselkedéssel, az észlelt viselkedési kontroll szerepe elhanyagolható; míg azoknál a viselkedéseknél, ahol erôs a személytól nem függó befolyások szerepe, az észlelt viselkedési kontroll lesz erôs, a szándék pedig gyengébb. Hangsúlyosnak tartotta a két elem eltéró hozzájárulását a viselkedés magyarázatához: „bármelyik adott alkalmazásnál az egyik fontosabb lehet, mint a másik, és tulajdonképpen lehet, hogy csak az egyik prediktorra lesz szükség" (Ajzen, 1991, 185. o.). Ezt a feltételezést a szakirodalmi eredmények nem támasztják alá, ahogy azt Ajzen (1991) is megállapította, noha késóbbi kutatások közül volt, ami alátámasztotta a szándék-észlelt viselkedési kontroll interakció hipotézisét (Terry \& O'Leary, 1995).

Armitage és Conner (2001) metaelemzése nem talált elegendố tanulmányt ahhoz, hogy következtetést lehessen levonni az interakció létéról. 19 tanulmány foglalkozott az interakcióval, ebból 9 talált interakciós hatást, mindegyik esetében a magasabb észlelt viselkedési kontroll erősebb szándék-viselkedés kapcsolattal járt együtt. Tehát ezek az eredmények sem azt igazolják, hogy erôsebb észlelt viselkedési kontroll esetében a szándék szerepe gyengülne. Az empirikus kutatások eredményei azt mutatják, hogy a viselkedéssel többnyire a szándék áll erósebb kapcsolatban, az észlelt viselkedési kontroll kapcsolata pedig gyengébb. Ez alól egy kivételt találtam: a testmozgás hosszabb idôn keresztül történó fenntartásával kapcsolatban néhány hónapos követési idố esetében az észlelt viselkedési kontrollt találták jobb prediktornak (Armitage, 2005; Skår, Sniehotta, Araújo-Soares, \& Molloy, 2008), míg több éves utánkövetésnél a szándékot (Plotnikoff, Lubans, Trinh, \& Craig, 2012), tehát a testmozgás hosszabb idốn keresztül történó fenntartása esetében vegyesek az eredmények. További kutatásokra lenne szükség annak eldöntésére, hogy az észlelt viselkedési kontroll nagyobb szerepe a viselkedés tárgyával (testmozgás) vagy idói kiterjedésével (középtávon fenntartott viselkedés) van-e kapcsolatban - elsósorban más viselkedéstípusok hosszabb távú fenntartását lenne tehát érdemes vizsgálni.

Az idézett eredményekból inkább az látható, hogy azoknál a viselkedéseknél, amelyeket hatékonyan jelez elóre a modell, mind a szándék, mind az észlelt viselkedési kontroll fontos prediktor, amelyeket gyengébben jelez a modell, azok esetében mindkettónek természetszerúleg alacsonyabb a magyarázó értéke, de ezeknél a viselkedéseknél is a szándék relatív hozzájárulása erôsebb. Mindez azt is jelenti, hogy általában az intervenciók során a szándék és az észlelt viselkedési kontroll erôsítése egyaránt fontos lehet. 


\subsubsection{Attitúd: egységes fogalom?}

A modell attitúdfogalma eltér az attitúd hagyományos háromtényezôs modelljétól, ami szerint az attitúdnek kognitív, affektív és viselkedéses összetevóje van (Ajzen \& Fishbein, 2005). A tervezett viselkedés elmélete szerint az attitúd tisztán értékelő (ez a háromtényezős modell affektív elemének feleltethetó meg), a kognitív tényezót az attitúdöt meghatározó viselkedéses hiedelmek képviselik, a viselkedés pedig a részben az attitûd által meghatározott szándék következménye (Ajzen, 2012; Ajzen \& Fishbein, 2005).

A modell eredetileg egységes attitúdfogalmat feltételez, pontosabban azt mondja, hogy a viselkedés különböző kimeneteiról alkotott hiedelmek egyfajta összegzódéseként pozitív vagy negatív attitúd alakul ki a személyben az adott viselkedéssel kapcsolatban. Viszonylag korán felmerült azonban, hogy az attitûd két tényezốre, egy értékeló és egy affektív faktorra bontható (Ajzen, 1991); más elnevezéssel instrumentális és tapasztalati (Francis és mtsai, 2004) vagy kognitív és affektív (Kraft és mtsai, 2005) tényezőre. A modell kézikönyve szerint az attitúd mérésénél törekedni is kell arra, hogy mind instrumentális tételek (az adott cselekvés eredményeire vonatkozó, pl. hasznos-haszontalan), mind tapasztalati tételek (milyen érzés a viselkedést végrehajtani, pl. kellemes-kellemetlen) egyaránt kerüljenek a tételek közé, csakúgy, mint globálisan értékeló jelzók (pl. jó-rossz) (Francis és mtsai, 2004). A két attitúdfaktor létét alátámasztják a kutatási eredmények (pl. Kraft és mtsai, 2005).

\subsubsection{Szubjektív norma és normatív hiedelmek}

A viselkedésre vonatkozó szándékot előre jelzô három tényezố közül többnyire a szubjektív norma szerepe a leggyengébb. Ezt okozhatja az, hogy bizonyos cselekvéseknél egyszerúen kevésbé fontos az észlelt társas nyomás, és inkább a személy attitúdje és észlelt viselkedési kontrollja döntô. A szubjektív norma gyengeségét azonban részben okozhatja a nem megfelelố mérési mód is: ha egy tétellel mérik, akkor gyengébb elóre jelzó ereje van, mint ha több tétellel történik a mérése (Armitage \& Conner, 2001). Egy másik kérdés szintén módszertani: az eredeti elmélet és mérési mód szerint a normatív hiedelem magának a hiedelemnek (egy adott referenciaszemélytól származó észlelt véleménynek) és a véleménnyel való együttmúködési motivációnak a szorzata. Az eredmények azonban azt mutatják, hogy az együttmúködési motiváció gyakran nem tesz hozzá a normatív hiedelemhez, sót gyengíti a normatív hiedelem és a szándék korrelációját (Ajzen, 1991).

Az elmélet eredeti formájában egységesnek tekintették a szubjektív normát; ma már megkülönböztetnek elóíró és leíró normát (Ajzen, 2012; Manning, 2009): az elsó azt jelenti, amit a személy számára fontos emberek el- 
várnak a személytól, a második pedig azt, amit ténylegesen vagy a személy által feltételezetten cselekszenek az adott viselkedéssel kapcsolatban. Az elóíró norma múködésének az az alapja, hogy a személy mennyire hajlandó együttmúködni a társas elvárásokkal a szankciók elkerülése érdekében; a leíró norma, azaz mások viselkedésének a megfigyelése pedig kulcsként szolgálhat a viselkedés megvalósításához, így a viselkedés követésére ösztönözhet (Manning, 2009).

A személy környezetében levó emberek viselkedése ugyanebben az értelemben szerepel az önszabályozás idóbeli elméletében is a viselkedéses prepotencia egyik elemeként (Hall \& Fong, 2007, részletesen lásd késóbb, a 4. részben). Manning (2009) a kétféle szubjektív norma hatását vizsgálta metaelemzésében. A viselkedéssel a leíró szubjektív norma erósebb kapcsolatban áll, mint az elóíró szubjektív norma: a páronkénti mintás elemzés adatai szerint a leíró norma kapcsolata a viselkedéssel 0,34, míg az elóíró normáé 0,28 , a listwise elemzésnél kb. egyforma erósségú volt a kapcsolat (az elóíró normáé 0,41, a leíróé pedig 0,40). A szubjektív norma két eleme az elmélet által feltételezett indirekt kapcsolat mellett közvetlen kapcsolatban is áll a viselkedéssel: a leíró normáé 0,31 , míg az elóíróé -0,17. Ez azt is jelenti, hogy az elóíró norma - nem várt módon - csökkentette a leíró norma kapcsolatát a viselkedéssel. Ezt a szerzó úgy magyarázza, hogy a leíró norma erősebben hathat a viselkedés kialakítására azoknál, akik ezzel egy idóben nem érzékelnek eloóró nyomást is a környezetüktól.

A gyakorlatban ez azt jelenti, hogy ha például valaki szeretné, hogy egy családtagja elkezdjen mozogni, akkor hatékonyabb, ha ô maga is elkezd testmozgást végezni és ezzel együtt nem gyakorol ezzel kapcsolatban nyomást a másikra. Ez az elnyomó hatás legerôsebben azoknál a viselkedéseknél jelentkezett, amelyek társadalmilag elfogadottak, inkább hasznosak, mint élvezetesek, a viselkedés idóben egybeesik az egyéb tényezók mérésével, és amikor a modell elemeinek mérési módja kompatibilis volt (tehát a viselkedésnek pontosan megfelelt). A leíró norma és a viselkedés közötti kapcsolat erősebb volt, ha több idó telt el a két tényezó mérése között; olyan viselkedéseknél, melyek társadalmilag nem helyeseltek, nem voltak annyira motiválóak vagy kellemesek. Az előíró norma esetében a viselkedéssel való kapcsolat vegyes eredményeket hozott. A szubjektív norma két eleme tehát két külön tényezônek tekinthetó; Manning (2009) azt javasolja, hogy az elemzésekben érdemes külön kezelni óket.

A normatív hiedelmek mérése során pontos kérdéseket teszünk fel arról, hogy a személy számára fontos konkrét személyek mit gondolnak az adott viselkedésról, illetve végzik-e az adott viselkedést. A referenciaszemélyek köre eltérhet attól függóen, hogy kik körében és milyen viselkedést vizsgálunk. Ezért elôzetesen fontos megvizsgálni, hogy az adott populá- 
ció esetében és az adott viselkedéssel kapcsolatban kik lehetnek a fontos referenciaszemélyek. Testmozgás esetében például a fontos referenciaszemélyek többnyire a családtagok, barátok és az egészségügyi dolgozók (Symons Downs \& Hausenblas, 2005).

\section{A tervezett viselkedés elméletének javasolt kiegészítése: a korábbi viselkedés}

A tervezett viselkedés elmélete elvileg nyitott arra, hogy a modellt kiegészítsék olyan tényezókkel, melyek a viselkedés előrejelzését javítják (Ajzen, 2011). A szakirodalom korán elkezdte keresni azokat a tényezóket, melyekkel ki lehetne egészíteni a tervezett viselkedés elméletét, hogy jobb prediktív és magyarázó ereje legyen a modellnek (Conner \& Armitage, 1998). ${ }^{6}$ A modell kiegészítésére javasolt tényezók közül a korábbi viselkedés szerepét tárgyalom részletesen; ez a tényezó átvezet a viselkedés többé-kevésbé tudatos irányításától az egészségviselkedések szempontjából fontos szokásszerú viselkedések részben automatizált irányításához.

A korábbi viselkedés (past behaviour) a jövóbeli viselkedés egyik legjobb prediktora (Ajzen, 2011; Armitage, 2005; Hall \& Fong, 2007; Norman, Conner, \& Bell, 2000; Ouellette \& Wood, 1998). Mind az indokolt cselekvés elmélete, mind a tervezett viselkedése elmélete esetében növelte a modell prediktív erejét a múltbeli viselkedés modellbe illesztése (Ajzen, 1991, $2002 b$ ); a korábbi viselkedés a jövóbeli viselkedés független prediktora. Metaelemzések egyrészt jelentôs korrelációt találtak a korábbi viselkedés és a tervezett viselkedés elméletének elemei között, másrészt a korábbi viselkedés az aktuális viselkedés és a szándék prediktoraként növelte a megmagyarázott varianciát (Conner \& Armitage, 1998; Hagger és mtsai, 2002; McEachan és mtsai, 2011; Ouellette \& Wood, 1998; részletes adatok a 3. táblázatban).

A korábbi viselkedés a viselkedés varianciájának magyarázatához 11-13\%-ot tesz hozzá, a szándék varianciájának megmagyarázott arányát pedig 5-7\%-kal növeli (Conner \& Armitage, 1998; McEachan és mtsai, 2011). ${ }^{7}$ A metaelemzések egy része szerint a szándéknak (Conner \& Armitage,

\footnotetext{
${ }^{6}$ Conner és Armitage (1998) tanulmánya hat tényezót javasolt a modell kiegészítésére: a hiedelmek kiemelkedố voltát (salience), a korábbi viselkedést, az énhatékonyságot, a morális normákat, a szelfidentitást és az affektív hiedelmeket.

7 Hagger és munkatársai (2002) eredményei ebben nem szerepelnek, mivel elemzésükben a tervezett viselkedés elméletének elemei mellett az énhatékonyság is szerepel, ezért az értékek nem összevethetók.
} 
3. táblázat. A korábbi viselkedés kapcsolata a tervezett viselkedés elméletének elemeivel

\begin{tabular}{|c|c|c|c|c|}
\hline & $\begin{array}{c}\text { Conner \& } \\
\text { Armitage, } \\
1998 \\
\end{array}$ & $\begin{array}{l}\text { Ouellette \& } \\
\text { Wood, } 1998\end{array}$ & $\begin{array}{l}\text { Hagger és } \\
\text { mtsai, } 2002\end{array}$ & $\begin{array}{l}\text { McEachan és } \\
\text { mtsai, } 2011\end{array}$ \\
\hline Vizsgált viselkedés & vegyes & vegyes & testmozgás & $\begin{array}{c}\text { egészségvisel- } \\
\text { kedések }\end{array}$ \\
\hline $\begin{array}{l}\text { Az elemzett vizsgálatok } \\
\text { száma }{ }^{a}\end{array}$ & $11 / 12 ; 5 / 7^{b}$ & & $72 / 79$ & $206 / 237$ \\
\hline $\begin{array}{l}\text { Korábbi viselkedés } \\
\text { és viselkedés }\end{array}$ & $0,68^{c}$ & 0,39 & $0,64^{\mathrm{d}}$ & $0,50^{\mathrm{d}}$ \\
\hline $\begin{array}{l}\text { Korábbi viselkedés } \\
\text { és szándék }\end{array}$ & $0,51^{\mathrm{c}}$ & 0,43 & $0,58^{\mathrm{d}}$ & $0,47^{\mathrm{d}}$ \\
\hline $\begin{array}{l}\text { Korábbi viselkedés } \\
\text { és attitúd }\end{array}$ & $0,35^{c}$ & 0,30 & $0,39^{\mathrm{d}}$ & $0,32^{\mathrm{d}}$ \\
\hline $\begin{array}{l}\text { Korábbi viselkedés } \\
\text { és szubjektív norma }\end{array}$ & $0,28^{c}$ & 0,09 & $0,05^{\mathrm{d}}$ & $0,22^{\mathrm{d}}$ \\
\hline $\begin{array}{l}\text { Korábbi viselkedés } \\
\text { és észlelt viselkedési } \\
\text { kontroll }\end{array}$ & $0,36^{c}$ & $-0,36$ & $0,23^{\mathrm{d}}$ & $0,33^{\mathrm{d}}$ \\
\hline $\begin{array}{l}\text { Korábbi viselkedés } \\
\text { hozzájárulása a visel- } \\
\text { kedés predikciójához }\end{array}$ & $13,0 \%$ & & $\begin{array}{c}19,3 \%^{\mathrm{f}} \\
17,61 \%^{\mathrm{g}}\end{array}$ & $10,9 \%$ \\
\hline $\begin{array}{l}\text { Korábbi viselkedés } \\
\text { hozzájárulása a szándék } \\
\text { predikciójához }\end{array}$ & $7,2 \%$ & & $\begin{array}{l}15,68 \%^{f} \\
9,88 \%^{g}\end{array}$ & $5 \%$ \\
\hline
\end{tabular}

Megjegyzés:

a Az elsố szám az elemzett tanulmányok számát, a második az elemzett adatsorok számát jelenti.

b Az elsố két szám a korábbi viselkedés és a szándék, a második két szám a korábbi viselkedés és a viselkedés kapcsolatát vizsgáló tanulmányok és adatsorok száma.

c Az elemszámmal korrigált korreláció.

d A mintavétel hibájával és a mérési hibával korrigált korreláció.

e A korábbi viselkedés által megmagyarázott variancia a tervezett viselkedés elméletének prediktorain kívül.

${ }^{\mathrm{f}}$ A tervezett viselkedés elméletének eredeti prediktoraihoz az énhatékonyság és a korábbi viselkedés által együttesen hozzátett megmagyarázott variancia. Az eredeti modell a viselkedés $27,41 \%$-át magyarázta, az énhatékonysággal és a korábbi viselkedéssel kiegészített modell a 46,71\%-át, a szándék esetében pedig az eredeti modell a variancia $44,50 \%$-át, a kiegészített modell a 60,18\%-át magyarázta. A táblázatban a két érték különbsége látható.

g A tervezett viselkedés elméletének eredeti prediktorai mellett az énhatékonyságot is tartalmazó modellhez a korábbi viselkedés által hozzátett megmagyarázott variancia. Az énhatékonysággal kiegészített modell a viselkedés varianciájának 29,10\%-át, a szándék varianciájának 50,3\%-át magyarázta, a korábbi viselkedés hozzáadásával a két érték 46,71\%, illetve $60,18 \%$. A táblázatban a két érték különbsége látható. 
1998), más elemzések szerint a viselkedésnek jobb prediktora a korábbi viselkedés (Hagger és mtsai, 2002; McEachan és mtsai, 2011). A viselkedéssel mutatott korrelációi 0,39-0,68 között, míg a szándékkal mutatott korrelációi 0,43-0,58 között változnak. A korábbi viselkedés szignifikánsan csökkenti a viselkedés mindkét közvetlen prediktorának hatását (Hagger és mtsai, 2002; McEachan és mtsai, 2011; Skår és mtsai, 2008). A tervezett viselkedés prediktorai tehát részben összefüggenek a korábbi viselkedéssel; a korábbi viselkedés az észlelt viselkedési kontrollt (énhatékonyságot) növeli, az attitúdöt pedig kedvezóbbé teszi, így valószínúbbé teszi a szándékot és a viselkedést (Armitage, 2005; Conner \& Armitage, 1998; Hagger és mtsai, 2002; McEachan és mtsai, 2011; Ouellette \& Wood, 1998).

Ajzen (2011) szerint ezek az eredmények inkább a viselkedés stabilitását igazolják, illetve részben módszertani okokból erednek: a korábbi és a jövóbeli viselkedés mérési módja természetszerúleg közelebb áll egymáshoz, mint az elmélet többi eleméé. A korábbi viselkedés modellbe foglalását nem támogatja, mivel az nem lehet a szándék oki előzménye. A korábbi viselkedés szándékkal mutatott összefüggése Ajzen szerint nyitott kérdés egyelőre: próbálták egyéb tényezókkel (pl. anticipált affektussal vagy szelfidentitással) magyarázni, sikertelenül. Hall és Fong (2007) szerint a fő probléma az lenne azzal, ha a tervezett viselkedés elméletét kiegészítenék a korábbi viselkedéssel, hogy ennek nincs elméleti megalapozottsága, csak utólagos hozzátoldás lenne.

A korábbi viselkedés megfelelố számú ismétlódéssel - stabil környezetben, valamint gyakran elóforduló viselkedések esetén - szokássá válhat és jelentôs részben automatizálódhat. Az automatikus viselkedés egyik lehetséges magyarázata az, hogy a környezeti kulcsok hatására gyorsan, minimális figyelmi kapacitás lekötésével, tudatos döntés és tudatos szándék nélkül is elindulhat a cselekvés (Hall \& Fong, 2007; Ouellette \& Wood, 1998). A korábbi viselkedésnek a tervezett viselkedés elméletétól független elóre jelzó szerepe tehát származhat abból, hogy a tervezett viselkedés elmélete elsósorban a tudatos viselkedésirányításra vonatkozhat, azonban a viselkedés nemcsak tudatos, hanem automatikus folyamatok által is vezérelt, különösen gyakran végzett viselkedéseknél (Ouellette \& Wood, 1998). Ajzen ugyanakkor nem ért egyet azzal, hogy a szokások esetében habituációról van szó, és a környezeti kulcsok indítják a cselekvést (Ajzen, 2002b). Szerinte a tervezett viselkedés elméleti keretén belül is magyarázatot lehet adni a viselkedések automatizálódására: a gyakran elóforduló viselkedések esetében az attitúdök és a szándék automatikusan, tudatos ellenórzés nélkül aktiválódnak és irányítják a viselkedést (Ajzen, 2002b).

A szokássá vált múltbeli viselkedés a viselkedésnek egyfajta alapértékét (default) jelenti. Ha ez a viselkedés egybeesik a szándékkal, akkor meg- 
könnyíti a viselkedés jövóbeli megvalósítását: a viselkedés nagyrészt automatikusan, a kognitív erőforrásokat kevésbé felhasználva zajlik le. Előfordulhat azonban olyan helyzet is, amikor a szándék pontosan a szokás megváltoztatására irányul. Ilyenkor a korábbi viselkedés akadályozhatja a szándék megvalósítását; az új szokás kialakításához elsốsorban tudatos folyamatokra van szükség, és arra, hogy a szándék legyen elég erốs, a viselkedés megvalósításához szükséges készségek pedig legyenek elegendőek ahhoz, hogy az új szándéknak megfeleló viselkedés ismételt megvalósításával a régi szokás erejét legyốzze a személy (Ouellette \& Wood, 1998).

Egészségviselkedések esetében különösen fontos figyelembe venni, hogy a szándék és a szokás egymást erósíti vagy egymással ellentétes, hiszen vannak olyan egészségviselkedések, melyek egy jó szokás fenntartását jelentik (pl. ha valaki már elkezdett rendszeresen mozogni, akkor a testmozgás fenntartása), mások rossz szokás leküzdését (pl. a dohányzás abbahagyása vagy a testmozgás elkezdése egy mozgásszegény életmódot folytató személy esetében). Ezeknél az egészségviselkedéseknél tehát eltéró lehet mind a viselkedés irányításának tudatossága, mind a múltbeli viselkedés szerepe. Ez egyben azt is jelenti, hogy az önszabályozó kapacitást (lásd késóbb, a 3.2.2. részben) eltérô mértékben veszik igénybe azok a viselkedések, amelyek a korábbi szokással összhangban történnek, és azok, amelyek épp azok megváltoztatására irányulnak.

A viselkedés gyakoriságától is függ, hogy a korábbi viselkedés milyen összefüggést mutat a késóbbivel. A napi vagy heti rendszerességgel ismétlődő, stabil kontextusban játszódó viselkedések esetében erősebb a kettő közötti összefüggés, mint az évente vagy ritkábban végrehajtott viselkedéseknél (pl. szúróvizsgálaton való megjelenés). Ouellette és Wood metaelemzésében (1998) a rendszeres viselkedések esetében mind a késóbbi viselkedéssel, mind a szándékkal erósebb a korábbi viselkedés korrelációja, mint a ritka viselkedéseknél: a gyakran ismétlődô viselkedések esetében a viselkedéssel 0,59, a szándékkal 0,60 a korábbi viselkedés korrelációja; a ritka eseményeknél pedig 0,29, illetve 0,32. További különbség, hogy a ritkább viselkedések esetében erôsebb a kapcsolat a szándék tudatos prediktorai (az attitúd és a szubjektív norma) és a szándék között, mint a szokásoknál. A szerzók szerint ez is azt mutatja, hogy a ritka viselkedéseknél tudatos viselkedésirányításra van szükség, míg a gyakoribb viselkedéseknél kisebb a tudatos tényezók szerepe. Végül eltér a korábbi viselkedés és a szándék szerepe a viselkedés magyarázatában: mindkét típusú viselkedésnél mind a korábbi viselkedés, mind a szándék előre jelzi a viselkedést, azonban ritka viselkedéseknél a szándék elôre jelző szerepe lesz erôsebb $(\beta=0,62$ vs. $\beta=0,12)$, gyakori viselkedéseknél a korábbi viselkedésé ( $\beta=$ 0,45 vs. 0,27) (Ouellette \& Wood, 1998). 
Vitatott, hogy a szokás mennyi idó alatt alakul ki. Az elméletek egy része (pl. a transzteoretikus változásmodell; Prochaska, DiClemente, \& Norcross, 1992) fél évre teszi azt az intervallumot, ami után már viselkedésfenntartásról beszélhetünk. Ezzel ellentétben testmozgással kapcsolatban Armitage (2005) úgy találta, hogy az edzóterembe járás szokásának kialakulása öt hétig tartott, a hatodik héttól nem volt hatása a részvételnek vagy a részvétel kihagyásának az elkövetkezố viselkedésre. A szokás kialakulásának idói kerete tehát további kutatást igényel.

\section{A szándékon túl}

\subsection{A szándék-viselkedés diszkrepancia}

által felvetett egyes kérdések áttekintése: a viselkedésváltozás szakaszolása, önszabályozás és implicit hatások

Láttuk, hogy a tervezett viselkedés elmélete a viselkedés varianciájának mintegy 19-34\%-át magyarázza, ehhez a korábbi viselkedés újabb 11-13\%-ot ad hozzá. Az elmélet - és több más pszichológiai modell középpontjában álló szándék Sheeran (2002) 10 metaelemzésból készített metaelemzése szerint a viselkedés varianciájának $28 \%$-át magyarázza prospektív tanulmányokban. Ez nagy hatásméretnek számít, azonban a viselkedés varianciájának elég nagy részét hagyja magyarázat nélkül. Ez egyben azt is jelenti, hogy a szándék kialakulása utáni időszakban is vannak olyan lényeges tényezók, melyek befolyásolják a viselkedés megvalósítását.

A szakirodalomban vitatott kérdés, hogy a viselkedésváltozást kontinuumnak vagy külön szakaszokból álló folyamatnak érdemes-e tekinteni (pl. Rutter \& Quine, 2002; Schwarzer, 2008; Weinstein, Rothman, \& Sutton, 1998). A tervezett viselkedés elmélete a folyamatmodellek közé tartozik. Ezek az elméletek nem feltételeznek külön szakaszokat; a viselkedést a szándék következményének tartják, és feltételezik, hogy a szándékot magyarázó tényezók bármelyikére hatást gyakorolva növelhetô a viselkedés iránti szándék, ebból következóen a viselkedés megjelenése. E modellek legnagyobb problémája azonban pontosan a szándék és a viselkedés között tapasztalható eltérés. A szándékot pontosabban magyarázzák, mint magát a viselkedést (Schwarzer, 2008), ahogy azt a tervezett viselkedés elmélete esetében is láttuk. A szakirodalomban így megjelentek és népszerúek azok az elméletek, melyek minóségileg is elkülöníthetố szakaszokra osztják a viselkedésváltozást (Rutter \& Quine, 2002; Schwarzer, 2008; Weinstein és mtsai, 1998). Legismertebb és legszélesebb körben kutatott talán Prochaska transzteoretikus változásmodellje, amely - legelterjedtebb formájában - öt 
szakaszra osztja a viselkedésváltozást (Prochaska és mtsai, 1992; Schwarzer, 2008). Szintén teljes modell Weinstein 7 szakaszból álló elôvigyázatosság-alkalmazás folyamatmodellje (Precaution Adoption Process Model PAPM; Rutter \& Quine, 2002; Weinstein és mtsai, 1998).

A szakaszmodellek felfogásából az következik, hogy mindegyik szakaszban eltéró folyamatok zajlanak az egyénben, és más-más intervencióra van szükség, attól függóen, hogy az egyén melyik szakaszban van. A tiszta szakaszolást elméleti szempontból is sokan megkérdójelezik (Rutter \& Quine, 2002), és empirikusan is nehéz az elkülöníthetố szakaszokat igazolni (pl. Armitage, 2005; Etter \& Sutton, 2002; Marshall \& Biddle, 2001). Az elméletek harmadik típusa, például az egészségcselekvés folyamatmegközelítése (Health Action Process Approach - HAPA; Schwarzer, 2008) ezért arra törekszik, hogy a folyamatmodellel ötvözzön valamiféle szakaszolást. A viselkedésváltozást többnyire a szándék kialakulásáig tartó motivációs szakaszra és az azt követô akarati (volitional) vagy viselkedéses szakaszra bontják; az akarati/viselkedéses szakaszon belül pedig többnyire a viselkedésváltozás kezdeti és a viselkedést fenntartó szakaszra osztják a folyamatokat (Schwarzer, 2008).

A szándék kialakulása utáni szakasz egyben a szelfreguláció (önszabályozás) szakasza is, hiszen különösen a viselkedésváltoztatás kezdetén a személy a megszokott mintáival szemben cselekszik, tehát a szokásos viselkedését gátolnia, az új viselkedését pedig megvalósítania kell. Az önszabályozás azt jelenti, hogy egy bizonyos cél érdekében kontrollt gyakorolunk saját magunkon, és a spontán tanult, szokásos vagy velünk született viselkedés helyett szándékvezérelt módon cselekszünk (Baumeister, Gailliot, DeWall, \& Oaten, 2006; Hagger, Wood, Stiff, \& Chatzisarantis, 2009; Sniehotta, Schwarzer, Scholz, \& Schüz, 2005). Az önszabályozás nehézségét az adja, hogy önkontroll szükséges hozzá, ami viszont eróforrásigényes, és egyes megközelítések szerint - korlátozottan áll a személy rendelkezésére (Hagger és mtsai, 2009; Hall \& Fong, 2007; Muraven \& Baumeister, 2000). Önszabályozást igényló helyzetekben tehát ezt a korlátozott eróforrást használja a személy, ami azt is jelenti, hogy idóvel kimerülhet az eróforrás. Ebben a szakaszban minden olyan tényező, ami csökkenti az önszabályozó kapacitás leterheltségét, elősegítheti a szándék sikeres megvalósítását. Ilyenkor sokszor már inkább gyakorlati módszerekról van szó.

E szakasz leggyakrabban kutatott módszere a tervezés, amely azzal segít elsósorban, hogy nem in situ kell dönteni, hanem a tervek alapján minimális tudatos odafigyeléssel tud a szándékának megfeleló módon cselekedni a személy. A tervek szerepe már a 60-as években felmerült (Leventhal, Singer, \& Jones, 1965), a jelenlegi szakirodalomból pedig két munkacsoport kutatásait érdemes kiemelni a tervekkel kapcsolatban. Gollwitzer szándék- 
megvalósításnak (implementation intentions) nevezi azokat a terveket, melyek konkrét szituációkra készülnek: „Amikor x szituáció felmerül, y-t fogom tenni" (Gollwitzer, 1999, 494. o.). Schwarzer munkacsoportja kétféle tervet különböztet meg, melyek a már említett egészségcselekvés folyamatmegközelítési modellnek is részei (pl. Schwarzer, 2008; Sniehotta és mtsai, 2005). A tervek egyike arra vonatkozó konkrét terveket jelent, hogy egy cselekvést mikor, hol és hogyan hajtunk végre. Ez a cselekvéstervezés (action planning), amely a tervek megfogalmazásának formai különbségei ellenére összevethetó Gollwitzer szándékmegvalósítás-fogalmával. A tervek másik típusa a megküzdéstervezés (coping planning), amely bizonyos akadályok felmerülésének esetére készített terveket jelent. A tervek részletesebb tárgyalása meghaladja tanulmányom kereteit.

Még egy tényezót érdemes figyelembe venni, amikor hosszabb idôn át tartó cselekvések megvalósításáról van szó, különösen a viselkedésváltozási folyamat kezdetén, vagy - más okok miatt - amikor már átalakult szokássá a viselkedés. A tudatos és racionális viselkedésirányítás mellett szerepet játszhatnak, sôt, amikor a viselkedés tényleges megvalósítására kerülne a sor, gyakran döntố szerepet játszanak az implicit hatások vagy éppen az impulzív döntések és az érzelmek (Hofmann, Friese, \& Wiers, 2008). E viselkedések hosszú távú tervezést, viselkedéskövetést igényelnek, ennek során pedig az impulzív hatások gátlását. Mindez szintén önszabályozást, a végrehajtó funkciók múködését igényli.

A szándék és viselkedés közötti kapcsolat tökéletlenségét más szempontból magyarázza Hall és Fong (2007). Szerintük az emberi viselkedést nagymértékben befolyásolják a viselkedés azonnali következményei, és a szándék-viselkedés diszkrepanciát az okozhatja, hogy egy hosszú távon elónyös viselkedés rövid távon kényelmetlenséggel jár, és a tényleges cselekvést gyakran az utóbbi határozza meg. Ezért figyelembe kell venni az idôi perspektívát, valamint az ebben meglévố egyéni különbségeket is (Hall \& Fong, 2007; Zimbardo \& Boyd, 1999), ami már továbbvezet bennünket az önszabályozás idóbeli elméletéig (Hall \& Fong, 2007, részletesen lásd késóbb, a 4. részben).

\subsection{Az önszabályozás}

\subsubsection{Az önszabályozás fogalma}

Az egészségviselkedések megvalósítása érdekében a szándék mellett tehát önszabályozásra, önkontrollra is szükség van; a hétköznapi szóhasználat ezt nevezi akaraterónek. Önszabályozásnak (szelfregulációnak) tekinthetjük, ha a személy kognitív, érzelmi és viselkedéses forrásokat mozgósít an- 
nak érdekében, hogy az automatikus, természetesen jövő viselkedését megváltoztassa egy vágyott cél vagy kimenet érdekében (Bauer \& Baumeister, 2011; Baumeister és mtsai, 2006; Hagger és mtsai, 2009; a terminológiával kapcsolatban lásd még Lewis \& Todd, 2007 gondolatmenetét).

A szelfreguláció tehát valamilyen viselkedés érdekében kifejtett tervezést és kontrollt igényel; tudatos, akaratlagos és célirányos (Hagger, 2010). Ennek során gyakran arra van szükség, hogy egy rövid távú előnyökkel járó viselkedés helyett egy rövid távon többletráfordítással, hátrányokkal, kényelmetlenséggel járó viselkedést válasszunk egy hosszú távon előnyös cél elérése érdekében. Ez azt is jelenti, hogy a cselekvések idói perspektívája, valamint az idôi perspektívában jelentkezó egyéni különbségek fontos szerepet játszhatnak a szelfregulációban (Hall \& Fong, 2007; Zimbardo \& Boyd, 1999). A viselkedések hosszú távú megtervezése, illetve a konkrét helyzetekben az egyes cselekvési alternatívák közötti választás, a viselkedések elkezdése, más viselkedések gátlása a végrehajtó funkciók múködésétól függ, és önkontrollt (szelfkontrollt, énkontrollt) igényel.

Az önszabályozás funkciói nagymértékben egybeesnek a végrehajtó funkciók szerepével (Blair \& Ursache, 2011). A végrehajtó funkciók közé több, egymástól elválasztható, de egymással összefüggố múködés tartozik (Miyake és mtsai, 2000); ezek teszik lehetóvé, hogy az emberi viselkedés rugalmas, célirányos és a társas szabályoknak is megfeleló legyen (Blair \& Ursache, 2011). Továbbá, ezek múködésével válik lehetségessé, hogy egy ingerre lassabb, az azonnali automatikus emocionális választ felülíró akaratlagos, reflexión alapuló válasz szülessen (Lewis \& Todd, 2007; Posner, Rothbart, Sheese, \& Tang, 2007). Mindezek a funkciók gyakorlatilag egybeesnek az önszabályozás funkcióival is. Az önszabályozás szakirodalma az önszabályozást kifejezetten akaratlagos, tudatos folyamatnak tartja. Az önszabályozás tudatos, akaratlagos aspektusai szinonimának tekinthetók a végrehajtó funkciókkal; azonban ha figyelembe vesszük az önszabályozás automatikusabb aspektusait (pl. az érzelem és az arousal szabályozását), akkor ebból a szempontból ezek az aspektusok befolyásolják a végrehajtó funkciók múködését (nem pedig fordítva). Így inkább kétirányú kapcsolat van az önszabályozás különböző aspektusai és a végrehajtó funkciók között: a felülról lefelé irányuló szabályozásban a végrehajtó funkciók az önszabályozás elsődleges mechanizmusait jelentik, azonban emellett léteznek alulról felfelé irányuló folyamatok is: az érzelmi és motivációs állapotok, melyek befolyásolják a kognitív múködés egészét, így a végrehajtó funkciókét is (Blair \& Ursache, 2011; Lewis \& Todd, 2007).

A végrehajtó funkciók múködése idósebb korban csökkenhet (Blair \& Ursache, 2011), részben a munkamemória csökkenó kapacitása miatt, ami a szükséges információ fenntartását és rugalmas kezelését végzi, részben 
a gátló folyamatok gyengébb múködése, valamint az információfeldolgozás csökkent sebessége miatt. Emiatt idősebb korban az önszabályozást igénylő folyamatok is nehézségekbe ütközhetnek.

\subsubsection{A szelfkontroll erómodellje}

A szelfkontroll erômodellje ${ }^{8}$ (Hagger és mtsai, 2009; Muraven \& Baumeister, 2000) energiaterminusokban fogalmazza meg az önkontroll múködését. A modell szerint az énkontrollerô kapacitása korlátozott, és minden olyan cselekvés, amely énkontrollt igényel, ezt a kapacitást veszi igénybe. Ebból az következik, hogy hosszabb ideig tartó igénybevétel hatására az énkontrollerô kimerül, ezt nevezik énkimerülésnek (ego-depletion) (Bauer \& Baumeister, 2011; Hagger és mtsai, 2009; Muraven \& Baumeister, 2000). Az énkontrollt igényló viselkedések végrehajtásának megvalósulása vagy elmaradása attól függ, hogy aktuálisan rendelkezésre áll-e elegendó énkontroll-kapacitás. A rendelkezésre álló kapacitás mértékében egyéni különbségek vannak, ez az elmélet alkotói szerint diszpozicionális jellegú, a személyiség fontos aspektusa (Baumeister és mtsai, 2006). A személy rendelkezésére álló energia (diszpozicionálisan és aktuálisan értelmezve is) az önszabályozás idóbeli elméletének (Hall \& Fong, 2007) is eleme, részletesen lásd késóbb (4. rész).

Az erómodellt többnyire laboratóriumi helyzetben vizsgálják az ún. kettós feladat paradigma segítségével: a kísérleti csoportnak az énkontroll-kapacitást igénybe vevó feladatot adnak, a kontrollcsoport hasonló, de énkontrollt nem igényló feladatot végez, majd mindkét csoport egy másik, az elôzốtól eltérố jellegú énkontroll-kapacitást igénylő feladatot kap. A kutatási eredmények azt mutatják, hogy a kísérleti csoport teljesítménye csökken a második feladat során. Az énkontrollt igényló tevékenységek köre változatos: kísértéseknek és impulzusoknak való ellenállás, érzelemszabályozás, gondolatok elnyomása, stresszes szituáció kezelése stb. (Bauer \& Baumeister, 2011; Hagger, Wood, Stiff, \& Chatzisarantis, 2010; Muraven \& Baumeister, 2000).

\footnotetext{
8 A szelfregulációval kapcsolatban több pszichológiai modell létezik. Az egyik legbefolyásosabb Carver és Scheier modellje, ami szerint a szelfreguláció visszacsatolási hurkok alapján múködik: a személy a jelenlegi állapotot összehasonlítja a kívánt állapottal, és ha eltérést tapasztal, akkor van szükség korrigálásra, azaz önszabályozásra. Az önszabályozó kapacitással kapcsolatban is több modell létezik: a kognitív elméletek sémaként vagy tudásstruktúraként fogják fel, a tanuláselméleti alapokon nyugvó elméletek pedig skillként vagy jól megtanult motoros programként (Bauer \& Baumeister, 2011; Hagger és mtsai, 2009). Az elméletek közül az önkontroll erómodelljét tárgyalom részletesebben, elsősorban azért, mert ez az elmélet illik bele a többi, itt tárgyalt elmélet által meghatározott gondolatmenetbe.
} 
Hagger és munkatársai (2010) 83 kísérleti tanulmány (198 független teszt) eredményeit összegezték metaelemzésükben. Az énkimerülés szelfkontrollra gyakorolt összesített korrigált hatásmérete közepes-nagy lett $(\mathrm{d}=0,62 ; 95 \% \mathrm{CI}=0,57-0,67 ; \mathrm{p}<0,001)$. Ugyanakkor vannak olyan kutatási eredmények is, melyek nem tudták replikálni az elméletet igazoló tanulmányok eredményeit (pl. Murtagh \& Todd, 2004; az ellentmondásos eredményeket Hagger és mtsai, 2010 metaelemzése is említi). Kérdéses az is, hogy ténylegesen a korlátozott kapacitás felelős-e az énkimerülésért vagy inkább a személy hiedelmei az akarateróról. Enyhe kimerülés esetén az énkimerülés nem jelentkezik azoknál, akik korlátlannak gondolják az akaraterôt (Job, Dweck, \& Walton, 2010), erős kimerüléskor viszont nincs ilyen hatása a hiedelemnek (Vohs, Baumeister, \& Schmeichel, 2013). Szintén a kognitív tényezók fontosságát mutatja az a feltevés, hogy lehet, hogy nem a tényleges, hanem az észlelt kimerülés számít. Azok, akik szituációs tényezônek tulajdonítják a kimerült állapotukat, jobb önszabályozásra képesek: tovább és jobb minóségben dolgoznak az önszabályozást igényló feladaton (Clarkson, Hirt, Jia, \& Alexander, 2010). Ezek az ellentmondásos eredmények azt mutatják, hogy az elmélet igazolására további kutatásokra van szükség.

Az önkontroll múködését az izmok múködéséhez hasonlítja a modell (Bauer \& Baumeister, 2011; Hagger és mtsai, 2009; Muraven \& Baumeister, 2000). Ebból az analógiából három feltételezés is ered (Hagger és mtsai, 2009; Hagger és mtsai, 2010). Az egyik az, hogy ugyanúgy, ahogy az izmoknak is szüksége van pihenésre a megfelelő múködéshez, az önkontroll-kapacitás is újratöltódik, ha a személy pihenhet. A megfelelố szintú önkontrolleró biztosításához tehát időról idő́re fel kell tölteni azt, figyelembe véve azt, hogy az önkontroll-kapacitás lassabban töltódik, mint ahogy lemerül. Az önkontroll-kapacitás „feltöltéséhez" kísérleti helyzetben eredményesen alkalmaztak pozitív érzelmeket, énmegerôsítést (a személyeknek a legfontosabb értékeikról kellett írniuk - ez után nem mutatták az énkimerülés jeleit), relaxációt és figyelemelterelést, valamint intrinzik motivációt (Bauer \& Baumeister, 2011; Hagger és mtsai, 2009).

Az izomanalógiából származó másik feltételezés, hogy az izmok edzéséhez hasonlóan az énkontroll gyakorlása rövid távon lemeríti a kapacitást, hosszú távon viszont növeli azt. A kutatási eredmények alátámasztják ezt a feltételezést: tehát bár közvetlenül az önkontrollt igénylő feladat után csökken a szelfregulációs kapacitás, hosszú távú rendszeres gyakorlása erôsíti azt, így kevésbé fordulnak eló az önszabályozó kapacitás kimerülése miatti önszabályozási kudarcok. Az ezt vizsgáló tanulmányok metaelemzése szerint a szelfkontroll-tréningben részt vevók jobb eredményt értek el a szelfregulációt igénylő feladaton és kevésbé voltak kimerültek 
$(\mathrm{d}=1,07 ; 95 \% \mathrm{CI}=0,10-2,03 ; \mathrm{p}<0,001 ;$ Hagger és mtsai, 2010). A harmadik feltételezés pedig az, hogy ugyanúgy, ahogy a sportolók az erejük beosztására törekednek, az önkontroll gyakorlása során is, ha a személy tudja, hogy további önkontrollt igénylő feladatok várnak rá, akkor beosztja az erejét, tehát az erô megốrzésére törekszik. Az eddigi kutatási eredmények ezt a feltételezést is alátámasztják (Bauer \& Baumeister, 2011; Baumeister és mtsai, 2006; Hagger és mtsai, 2009).

\subsubsection{A szelfreguláció fiziológiai szabályozása}

A szelfregulációt biztosító fiziológiai tényezók között vizsgálják a szelfreguláció idegrendszeri hátterét, elsôsorban az önszabályozásban részt vevő agyterületeket, valamint az önszabályozó kapacitás kimerülésének lehetséges fiziológiai alapját, a glükózszint változását önszabályozást igénylố helyzetekben. A szelfreguláció biológiai meghatározottsága szerepet kap az önszabályozás idóbeli elméletében is (részletesen lásd a 4. részben). A szelfreguláció különböző aspektusait - csakúgy, mint a végrehajtó funkciókét - a prefrontális kortex egyes területeihez köthetjük (Bush, Luu, \& Posner, 2000; Inzlicht \& Gutsell, 2007; Posner és mtsai, 2007; Wagner \& Heatherton, 2011).

A prefrontális kéreg három részból áll, a ventromediális és a laterális prefrontális kéregból, valamint az anterior cinguláris kéregból (Wagner \& Heatherton, 2011). A ventromediális prefrontális kéreg elsốsorban az önkontroll társas és érzelmi élettel, valamint a primer fiziológiai drive-okkal kapcsolatos vonatkozásainak szabályozását végzi. A laterális prefrontális kéreg elsősorban a viselkedések tervezésében és fenntartásában vesz részt; szerepe jelentôs az alapvetô végrehajtó funkciók múködtetésében (munkamemória, válaszgátlás). Sérülésekor a leghétköznapibb cselekvések elvégzése károsodik: az egyes cselekvések eltervezése és a cselekvés lépéseinek sorrendje, az irreleváns tényezóknek való ellenállás nem valósul meg, illetve általános motivációvesztés jelentkezik.

Az önszabályozással kapcsolatban kiemelkedô szerepe van az anterior cinguláris kéregnek (Bush és mtsai, 2000; Lewis \& Todd, 2007; Paus, 2001; Posner és mtsai, 2007), ami gazdag kapcsolatokkal rendelkezik a prefrontális kéreg másik két területével, különösen a laterális prefrontális kéreggel, amivel részt vesz a tervezésben és a magasrendú kognitív múködésben. Szintén vannak összeköttetései a motoros kéreggel és a gerincvelôvel, ami által a motoros területek szabályozásában vesz részt. Az érzelemszabályozásban részt vevô limbikus területekkel és az orbitofrontális kéreggel, valamint a jutalmazásban szerepet játszó központtal való kapcsolatok pedig azt biztosítják, hogy a szervezet arousalszintje és drive-állapotai befolyást gyakorolnak az anterior cinguláris kéreg múködésére (Paus, 2001), illetve 
az anterior cinguláris kéreg is tudja befolyásolni ezeket az agyterületeket (Lewis \& Todd, 2007). Mindezek alapján központi szerepet játszhat a szándékok cselekvéssé alakításában, tehát a cselekvés akaratlagos irányításában (Paus, 2001), illetve a más agyterületekból származó információ feldolgozásával fontos szerepe van a kogníció, az érzelem és a viselkedés szabályozásában, tehát magában a szelfregulációban (Posner és mtsai, 2007).

$\mathrm{Az}$ anterior cinguláris kéreg egyik fontos szerepe a konfliktusmonitorozás vagy hibadetekció (Blair \& Ursache, 2011; Falkenstein, Hoormann, Christ, \& Hohnsbein, 2000; Inzlicht \& Gutsell, 2007; Paus, 2001; Posner és mtsai, 2007; Wagner \& Heatherton, 2011). A hibadetekció múködése egy eseményhez kötött kiváltott potenciál, a hibázási negativitás (error-related negativity, ERN) megjelenésével jár együtt, ami egy erốs negatív hullám, 80 ms-mal a válasz után a legerósebb, és a dorzális anterior cinguláris kéregból ered (Falkenstein és mtsai, 2000; Inzlicht \& Gutsell, 2007). Minél könnyebben észrevehetô a hiba, annál nagyobb ez a negatív hullám, és / vagy annál hamarabb jelenik meg a hiba elkövetése után (Falkenstein és mtsai, 2000). Azonban nemcsak hibázás után jelenik meg negatív hullám, hanem kisebb negatív hullám a helyes válaszok után is mérhetó; ez azt jelenti, hogy a negatív hullám valószínúleg inkább az összehasonlítási folyamattal, tehát a válasz ellenórzésével jár együtt, nem a kimenettel (Falkenstein és mtsai, 2000).

A hibamonitorozás során az anterior cinguláris kéreg összehasonlítja a vágyott kimenettel az aktuálisan megvalósulót, és ha eltérést észlel, akkor jelez a prefrontális kéreg másik két területének, melyek a szabályozásban vesznek részt: megvalósítják a kívánt és elnyomják a nem kívánt választ (Blair \& Ursache, 2011; Inzlicht \& Gutsell, 2007; Wagner \& Heatherton, 2011). Azonban ha a konfliktust nem lehet megoldani, vagy az információ mennyisége meghaladja a személy képességét vagy eróforrásait, akkor a prefrontális kéreg múködése alacsony marad, az anterior cinguláris kéreg és a limbikus rendszer együttes múködése viszont stresszválaszt indít el, megnó az arousal, és nehézségek jelentkezhetnek a figyelem kontrollálásában és a végrehajtó funkciók múködtetésében (Blair \& Ursache, 2011). A mentális fáradtság a hibamonitorozás hatékonyságát csökkenti: Inzlicht és Gutsell (2007) kísérletében EEG-méréseket végeztek a kettôs feladat paradigma második tesztje (Stroop-teszt) során. A kísérleti csoportban (tehát akik korábban a szelfregulátoros kapacitást kimerítő feladatot kaptak) kisebb volt a hibázási negativitás, mint a kontrollcsoportban, és a hullám nagysága nem tért el a helyes és a hibás válaszok esetén, ami azt jelenti, hogy nem detektálták az eltérést a szándékolt és a tényleges válasz között. A hibamonitorozás hatékonyságának csökkenése okozhatja a szelfkontroll múködésének hiányosságait az énkimerülés állapotában. Újabb kutatási 
eredmények ennek az ellentétét is kimutatták: az implicit feladatokban nyújtott teljesítmény javul fáradtság esetén, amikor a kontrollfunkciók gyengébben múködnek (Delpouve, Schmitz, \& Peigneux, 2014).

Baumeister és munkacsoportja szerint a szelfregulációs kapacitás kimerülésének a vér glükózszintjének változása a fiziológiai alapja (Bauer \& Baumeister, 2011; Gailliot és mtsai, 2007; Gailliot \& Baumeister, 2007; Hagger és mtsai, 2009). A megfelelő önszabályozás feltétele a megfeleló vércukorszint: alacsony glükózszint vagy a glükóz nem megfeleló szállítása és metabolizmusa esetében romlik az önszabályozó képesség. Az önszabályozó kapacitást igénybe vevő feladat után esik a személyek vércukorszintje; ugyanakkor a vércukorszint növelésével megelőzhetô a teljesítmény romlása a további önkontrollt igényló feladatokban.

A glükóz szerepét vizsgálták figyelemkontroll-feladatokban, kutatták az impulzív viselkedéssel, illetve agresszióval mutatott összefüggéseit, alkoholfogyasztással és dohányzással való kapcsolatát, valamint a streszszel való megküzdésben és az érzelemszabályozásban betöltött szerepét. Utóbbi témában korrelációs és kísérleti tanulmányok egyaránt azt mutatják, hogy csökkent glükózszint esetén gyakoriak a negatív érzelmi állapotok (pl. szorongás, irritáltság, hangulatváltozások); ez a kapcsolat a csökkent glükóztoleranciával vagy diabétesszel élók esetében különösen erôs. A cukorbetegek számára különösen nehéz lehet az érzelemszabályozás, amikor nagyon alacsony a vérük glükóztartalma (Gailliot \& Baumeister, 2007).

A szénhidrátok, elsósorban a glükóz mentális múködésben betöltött szerepe azonban ennél összetettebb lehet: többféle mechanizmuson keresztül befolyásolhatják az agy múködését, és az eredmények sem feltétlenül enynyire egyöntetúek. Gibson (2007) tíz lehetséges mechanizmust sorol fel; ${ }^{9}$ a hatás ráadásul nem egyirányú: kognitív tényezók (elvárások, hiedelmek, érzelmi és motivációs állapotok) is befolyásolhatják a fiziológiai folyamatokat (Gibson, 2007). A téma részletes tárgyalása meghaladja e tanulmány kereteit, összességében azonban úgy túnik, az agymúködést nem befolyásolják jelentősen a vércukorszint változásai. Az agy glükózellátását saját rendszere, az asztrociták szabályozzák, melyek glikogént raktároznak, így hirtelen fellépó szükséglet esetén tudják biztosítani az agymúködéshez

\footnotetext{
9 A téma részletes tárgyalása meghaladja tanulmányom kereteit. Annyit azonban fontos megjegyezni, hogy a szabályozásban érintett a hipotalamusz-hipofízis-mellékvesekéreg tengely (HPA-tengely) is, ami stressz hatására kortizolt választ ki, ami viszont a glükózhomeosztázis egyik szabályozója. A kortizolnak azonban ellentmondásos szerepe van a mentális múködésekben: pl. bizonyos emlékanyag (az érzelmileg telített emlékek) elóhívását serkenti, másokét (semleges emlékekét, a munkamemóriát általában, a deklaratív memóriát és a térbeli gondolkodást igényló feladatokat) gátolja (Gibson, 2007; Gibson \& Green, 2002).
} 
szükséges glükózt (Gibson, 2007), ráadásul a vér glükózszintjének emelkedése esetén elôször az asztrociták glikogénraktárai töltődnek fel, a glükóz nem kerül azonnal közvetlenül a neuronokhoz (Gibson \& Green, 2002).

Kurzban (2010) tanulmánya részleteiben is megkérdójelezi a glükózhipotézist. A vér glükózszintje és az agy mentális funkciók során mutatott energiafelhasználása között összetettebb a kapcsolat: nem valószínú, hogy a véráramban mérhetố glükóz mennyisége tükrözi az agy egyes területeinek energiafelhasználását. Az agy energiafelhasználása egyébként is alacsony; a szelfkontrollfeladatok nem növelik jelentósen az energiafelhasználást. Az önkontrollt igénylő feladatok után nem minden esetben esik a vér cukorszintje; egyébként is, ha a glükózhipotézis igaz lenne, akkor a glükóz mennyiségét az agymúködésnél sokkal jobban csökkentó intenzív testmozgással lenne „érdemes” lemeríteni a kísérleti személyeket - a testmozgásról viszont azt mutatják az eredmények, hogy javítja a kognitív múködést. Kurzban (2010) nem ért egyet azzal sem, hogy a szelfregulációt igénylő feladatok során a glükózszint esését és nem az abszolút glükózszintet elemezték a szerzók: az elméletet inkább a glükóz tényleges szintje igazolná, nem a glükózszint változása, és a glükózszintet befolyásolják a szervezet endogén folyamatai is, tehát nemcsak a feladat során kifejtett erófeszítésnek van hatása. Mindezek a megfontolások azt mutatják, hogy a szelfreguláció glükózhipotézise nem tekinthetó igazoltnak, a téma további kutatást igényel.

\section{Elméleti integráció kísérlete: az önszabályozás idóbeli elmélete}

Az eddig tárgyalt elméletek segítségével áttekintést kaptunk a viselkedés szándékvezérelt jellegével kapcsolatos fóbb kutatási eredményekról és elméleti vitákról, a korábbi viselkedés felvetette a viselkedésszabályozás kevésbé tudatos aspektusait, a viselkedésváltozás motivációs szakaszát követô viselkedésmegvalósítási időszakával kapcsolatban pedig az önszabályozás által felvetett egyes kérdéseket tekintettük át, különös tekintettel az önszabályozás biológiai alapjaira. Mindezeket az elméleteket igyekszik új modellé szintetizálni és kibóvíteni az önszabályozás idóbeli elmélete (Temporal Self-Regulation Theory, Hall \& Fong, 2007; az elméletról szóló szakmai vitát lásd a Health Psychology Review 2010. évi 2. füzetében).

Az elmélet (2. ábra, Hall \& Fong, 2007, 14. o. alapján) középpontjában a szándék és viselkedés között feltételezett kapcsolat áll, hasonlóan a tervezett viselkedés elméletéhez, azonban a modell több szempontból meghaladja a tervezett viselkedés elméletét. Nem tisztán lineáris modell, hanem 


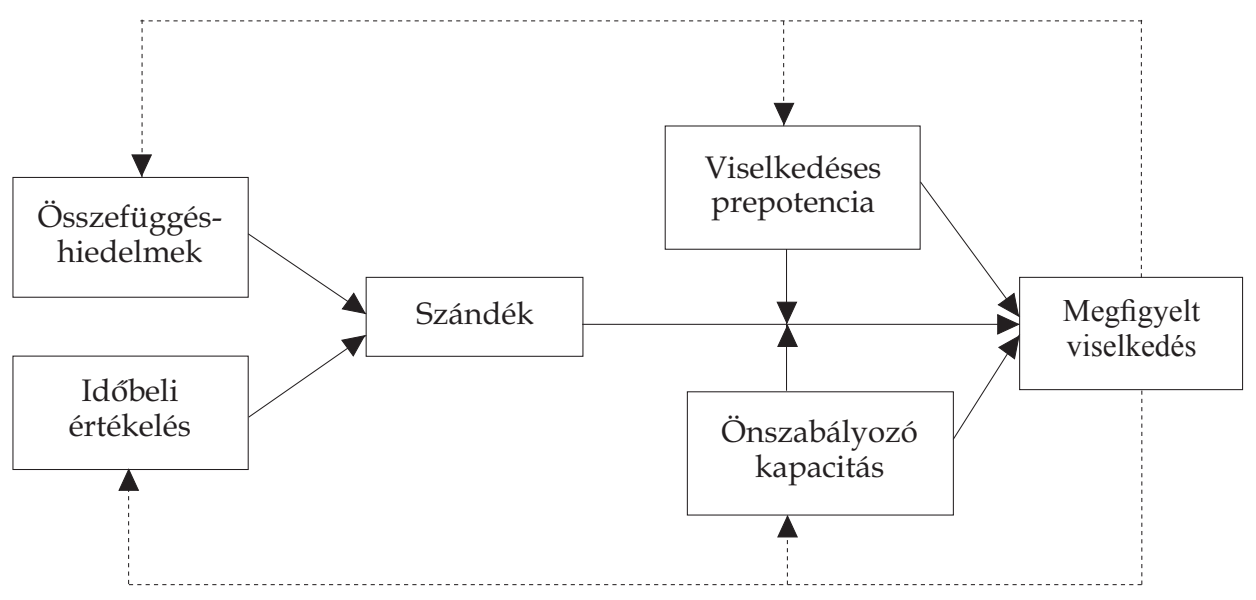

Motivációs szféra

Környezeti idóbeli kontingenciák (társas és fizikai környezet)

2. ábra. Az önszabályozás idóbeli elmélete

szakaszolást is tartalmaz: a motivációs szakasz után a társas és fizikai környezet által meghatározott szakasz következik.

A modell szerint a viselkedést a szándék befolyásolja, emellett pedig a viselkedéses prepotencia és a szelfregulátoros kapacitás hat rá közvetlenül és közvetetten (a szándék-viselkedés kapcsolat moderátoraként) is. A prepotens válasz egy adott helyzetben az elsóbbséget élvező válasz (Hall \& Fong, 2007). Három forrásból eredhet a prepotens viselkedés: biológiailag meghatározott drive-ok, hozzáférhető környezeti kulcsok és korábbi viselkedés. Ezek a „default” viselkedések sokszor automatikusan megtörténnek; más cselekvésekkel való helyettesítésükhöz akaratlagos szabályozásra, azaz a végrehajtó funkciók múködésére (önszabályozásra) van szükség. A viselkedéses prepotencia két elemból áll: „a múltbeli viselkedés gyakorisága és/vagy a cselekvési kulcsok jelenléte a környezetben" (Hall \& Fong, 2007, 15. o.). Korábban láttuk, a korábbi viselkedés a viselkedés legjobb előrejelzóje; ennek az elméletnek az újdonsága az, hogy a modell integráns részévé teszi a korábbi viselkedést. A környezeti kulcsok származhatnak akár a külsó, akár a belsố környezetból. A külsó környezetból származó kulcsok lehetnek a kérdéses viselkedést a személy környezetében megvalósító személyek is, így ez párhuzamba állítható a tervezett viselkedés elmélete szubjektív norma fogalmán belül a leíró normával. A prepotens viselkedés akkor segíti a viselkedés megvalósítását, ha egybevág vele, ha viszont ellentétes, akkor akadályozza azt - akkor van szükség erôs önszabályozásra mindaddig, amíg az új, kívánt viselkedés lesz a prepotens válasz. 
A másik, a viselkedésre közvetlen és közvetett hatással egyaránt bíró tényező a szelfregulátoros (önszabályozó) kapacitás. A szelfregulátoros kapacitás „bármilyen vonás- vagy állapotszerú tényező, amely befolyást gyakorol a személy kapacitására, hogy saját viselkedését akaratlagosan szabályozza" (Hall \& Fong, 2007, 15. o.). A szelfregulátoros kapacitást egyrészt a végrehajtó funkciók múködéseként, másrészt energizáltságként definiálja a modell. A végrehajtó funkciók a szelfreguláció tudatos formájának múködéséért felelősek és biológiailag meghatározottak. A szerzók feltételezése szerint részben a végrehajtó funkciók múködésében mutatkozó egyének közti különbség lehet a biológiai alapja az önszabályozásban mutatkozó egyéni különbségeknek. A szándék-viselkedés kapcsolatot közvetetten is befolyásolja az elmélet szerint a végrehajtó funkciók erôssége: a feltételezés szerint erôsebb végrehajtó funkciók esetén erôsebb kapcsolat várható a szándék és a viselkedés között (Hall \& Fong, 2007). Az önszabályozó kapacitás másik eleme a szokásosan vagy aktuálisan a személy rendelkezésére álló energia mennyisége, tehát a vonás- és állapotenergizáltság (Hall \& Fong, 2007).

A végrehajtó funkciók prediktív szerepét az egészségviselkedések esetében egyetemista résztvevókkel vizsgálták $(n=64$, illetve $n=121$; Hall, Fong, Epp, \& Elias, 2008). Go/NoGo feladatta ${ }^{10}$ mérték a végrehajtó funkciók múködését, majd felmérték, hogy a megelőző héten mennyi fizikai aktivitást végeztek (1. tanulmány), illetve mennyi gyümölcsöt és zöldséget fogyasztottak (2. tanulmány), valamint hogy a következó egy hétben milyen fizikai aktivitást szándékoznak végezni, illetve a gyümölcs- és zöldségfogyasztásra vonatkozó szándékukat szintén a következő hétre. Egy héttel késóbb ugyanezeket a kérdéseket tették fel nekik. Az eredmények mindkét viselkedésnél azt mutatták, hogy a mind a szándék, mind a Go/NoGo feladatban mutatott reakcióidó elóre jelezte a viselkedést, de ezek mellett a szándék és a reakcióidô interakciója is prediktív volt. Az erős és a gyenge végrehajtó funkciójúakból alkotott két csoportnál a szándék eltéró mértékben jelezte előre a viselkedést. Az erős végrehajtó funkciójúak esetében erôsen szignifikáns volt a szándék előre jelzó ereje (a testmozgást vizsgáló kísérletben: $\beta=0,97 ; \mathrm{t}=8,03 ; \mathrm{p}<0,001)$, míg a gyenge végrehajtó funkcióval rendelkezóknél szintén szignifikáns volt ugyan, de kevésbé $(\beta=0,31 ; t=2,19 ; p=0,03)$. A zöldség-és gyümölcsfogyasztással kapcsolatban hasonló eredményeket kaptak. A testmozgás varianciájának 61,1\%-át magyarázta a modell a korábbi viselkedés modellbe foglalásával; csak a

10 A feladat a prepotens válaszok gátlását méri. Szelektív reakcióidó-feladat; lényege, hogy egy bizonyos ingerre a lehetô leggyorsabban választ kell adni, az attól eltéró ingerre viszont nem szabad választ adni. 
szándék és a végrehajtó funkciók független és interaktív hatása pedig a variancia 58,5\%-át magyarázta. Az egészséges étkezés esetében ugyanezek az értékek $62,1 \%$, illetve $61,2 \%$ voltak. A modell által megmagyarázott variancia tehát még a korábbi viselkedés figyelembevétele nélkül is jelentôsen magasabb, mint a tervezett viselkedés elmélete által szokásosan megmagyarázott variancia.

Míg a végrehajtó funkciók esetében megnyilvánuló egyének közti különbség a szelfregulációban megnyilvánuló egyének közti különbséggel lehet összefüggésben, az önszabályozó kapacitás másik eleme az aktuálisan vagy általában a személy rendelkezésére álló energia mennyiségét mutatja (Hall \& Fong, 2007). Az elméletnek ez az eleme a szelfreguláció erómodelljének eredményeiból indul ki, tehát az önszabályozó kapacitás lehetséges kimerülését illeszti a modellbe. A vonásenergizáltság az általában a személy rendelkezésére álló energia mennyiségét jelenti, míg az állapotenergizáltság az adott helyzetben rendelkezésre álló energia menynyiségét, ami - ha korábban az energiamennyiség lemerült - lehet átmenetileg túl alacsony is, ami magyarázhatja az önszabályozás folyamatában bekövetkező botlásokat.

A modell szerint a szándékot két tényezó határozza meg. Az egyik az, hogy a személy mit gondol arról, hogy a viselkedésének milyen következményei lesznek, és hogyan értékeli az adott következményt (Hall \& Fong, 2007). Ezt a modell összefüggés-hiedelmeknek nevezi; ez az egyetlen elem, amelynek megfeleltethetó a tervezett viselkedés elméletének egy összetevôje, mégpedig az attitúdöt meghatározó viselkedési hiedelmek.

A szándékot meghatározó másik tényezó a viselkedés feltételezett elónyeinek és hátrányainak idóbeli távolsága a cselekvéstól, azaz az idóbeli értékelés (Hall \& Fong, 2007). Az egészségviselkedések zöme ugyanis rövid távon kellemetlenséggel, hátrányokkal jár inkább, jótékony hatásuk többnyire csak hosszú távon érezhetố. Ez azonban hátráltathatja az egészségviselkedések megvalósítását (pl. Ouellette \& Wood, 1998). Hall és Fong (2007) kiindulópontja ezzel kapcsolatban az, hogy az emberi viselkedésre általában erôs hatással vannak az azonnali következmények, ami nyilván csökkenti a szándék-viselkedés kapcsolatot.

A pszichológiai irodalomban régóta ismert, hogy az idóbeli távolság befolyást gyakorol a cselekvések szubjektív értékére: az idóbeli távolság növelésével a cselekvések szubjektív értéke csökken, azaz gyakran nagyobb értéket tulajdonítunk egy idóben közeli jutalomnak, mint egy idóben távolibb jutalomnak, akkor is, ha az idóben távolibb jutalom nagyobb (Trope \& Liberman, 2003). Az egyének között már gyermekkorban különbségek figyelhetók meg a tekintetben, hogy mennyire tudják a jutalmat késleltetni, azaz mennyire vannak stratégiáik (pl. a figyelmi folyamatok befolyá- 
solásával) arra, hogy képesek legyenek a közeli kisebb jutalom helyett a távolabbi, nagyobb jutalmat választani (Mischel, Ebbesen, \& Raskoff Zeiss, 1972). Ezek az óvodáskori különbségek összefüggnek a serdülókorban mért iskolai teljesítménnyel és bizonyos kompetenciákkal: akik 4 éves korban tovább tudtak várni a kívánatos jutalomra, azok serdülókorban jobb iskolai teljesítményt nyújtottak, és jobban tudták kezelni a stresszt és a frusztrációt (Mischel, Shoda, \& Rodriguez, 1989). Nemcsak a jutalomkésleltetésre vonatkozó stratégiákban lehet azonban különbség az egyének között, hanem abban is, hogy a gondolkodásukat, döntéseiket inkább a múlt, a jelen vagy a jövő befolyásolja, azaz a személyre jellemző idói perspektívában is (Zimbardo \& Boyd, 1999). A jövőorientáltság kapcsolatban áll több, az egyén számára pozitív következménnyel, például az egészségvédó viselkedésekkel is (Hall \& Fong, 2007; Zimbardo \& Boyd, 1999).

A cselekvések idói távolsága a reprezentációjuk szintjét is befolyásolja; ezzel is magyarázható a hedonisztikus érték változása. Az idóben távolabbi eseményeket, következményeket absztraktabb, a kontextustól függetlenített módon jelenítjük meg, míg a közelieket konkrétabban, kontextushoz kötődóen, részletgazdagabban (Trope \& Liberman, 2003). Ez a reprezentációs szint változás összefügg a hedonisztikus értékkel: ahogy az idóben távolodunk, egyre inkább a magasabb rendú, absztraktabb konstrukcióhoz kapcsolódó érték lesz erósebb. Tehát, ha egy viselkedés alacsony szintú értéke pozitívabb, mint a magas szintú értéke, akkor az a viselkedés a közeljövóben vonzóbb, nem a távolabbi jövóben (ez lehet a helyzet pl. a dohányzással); fordított esetben pedig, tehát amikor a magas szintú érték pozitívabb, mint az alacsony szintú, akkor pedig a távoli jövóben vonzóbb a cselekvés (mint pl. a testmozgás esetében). A reprezentációs szintek közötti különbség párhuzamba állítható a szándék és a viselkedés hagyományos mérése esetében tapasztalt mérésiszint-különbséggel, melynek kiküszöbölését a tervezett viselkedés esetében kiemelkedő fontosságúnak tartja Ajzen (Ajzen \& Fishbein, 2005). A tervezés szerepét is tekinthetjük részben annak, hogy a távoli absztrakt célhoz vezetô utat a tervezés segítségével próbáljuk meg konkrétabbá tenni, és ezzel a tényleges megvalósítás esélyét növelni.

\section{Megbeszélés}

A fenti narratív áttekintés alapján úgy túnik, hogy a tervezett viselkedés elmélete ugyan jól ismert, sokszor alkalmazott modell, azonban több ponton az eddiginél pontosabb megközelítésre van szükség vele kapcsolatban. Ezek közül elsósorban azt emelem ki, hogy gyakorlati szempontból is fontos a szubjektív norma két elemének, az elóíró és a leíró szubjektív 
normának a megkülönböztetése; ahogy láttuk, a viselkedéssel többnyire inkább a leíró szubjektív norma, tehát a személy számára fontos személyek tényleges viselkedése függ össze, nem az eredetileg feltételezett észlelt társas nyomás.

Az ismertetett szakirodalmi eredmények alapján árnyalható az egészségviselkedések megközelítése. Ki lehet indulni a szándék-viselkedés kapcsolatból, azonban az egészségviselkedések megvalósítását érdemesebb több szakaszból álló, a korábbi viselkedésból származó tapasztalatra épüló önszabályozó folyamatként megközelíteni. A szándék kialakulása után történik a viselkedés megvalósítása, ami - új egészségviselkedés esetében - felosztható a viselkedésváltoztatás és a viselkedés fenntartásának szakaszára. A folyamatban kiemelhetó a korábbi viselkedés hatása, a viselkedés tényleges megvalósítása pedig nagymértékben függ a viselkedés következményeinek észlelt idóbeli távolságától. Mindkettố lényeges gyakorlati szempontból is. Ha van a kívánt viselkedéssel megegyezó korábbi viselkedés, akkor a belóle származó tapasztalat nagymértékben segítheti a viselkedés megvalósítását, azonban ha a korábbi viselkedés a kívánttal ellentétes, akkor érdemes tudatosítani, hogy ez önmagában nehezíti a viselkedés megvalósítását. A viselkedés következményeinek észlelt idóbeli távolsága pedig azért fontos, mert gyakran elófordul, hogy a hosszú távon előnyös egészségviselkedés rövid távon nehézségeket, kellemetlenségeket okoz. Különösen a viselkedésváltoztatás szakaszában érdemes ezt tudatosítani, hiszen az elónyös új szokás kialakulása alatti hetekben-hónapokban különösen nagy a veszélye annak, hogy a rövid távon belül várt elônyök miatt (vagy a rövid távon belül várt kényelmetlenség elkerülése érdekében) a személy végül nem valósítja meg a hosszú távon előnyös viselkedést, és emiatt nem is tud a hosszú távon elónyös új szokás kialakulni.

Ha az egészségviselkedések megvalósítását önszabályozási folyamatnak tekintjük, akkor elkerülhetetlen az önszabályozás biológiai alapjainak vizsgálata. A végrehajtó funkciók, valamint a vonás- és állapotenergizáltság vizsgálata részben magyarázatot adhat az önszabályozásban megfigyelhetố személyek közötti különbségekre, másrészt viszont segítségével meg lehet határozni, hogy melyek azok az - akár átmeneti, akár tartósabb - állapotok, melyek során az önszabályozó kapacitás várhatóan alacsony szintje miatt egyéb technikák (pl. a tervezés) alkalmazására van szükség a viselkedés sikeres megvalósítása érdekében.

Az önszabályozás idóbeli elmélete a szándék-viselkedés kapcsolatra épít, de a modellbe integrálja a fenti elemeket is. Ígéretes új modell, azonban egyelóre kevés empirikus tapasztalat áll rendelkezésre vele kapcsolatban. Az empirikus igazolás mellett a kutatás egyik legfontosabb feladata jelenleg a modell elemeinek pontos operacionalizálása (Berkes, 2013). 


\section{Irodalom}

Ajzen, I. (1991). The Theory of Planned Behavior. Organizational Behavior and Human Decision Processes, 50(2), 179-211.

Ajzen, I. (1998). Models of human social behavior and their application to health psychology. Psychology \& Health, 13(4), 735-739.

Ajzen, I. (2002a). Perceived behavioral control, self-efficacy, locus of control, and the Theory of Planned Behavior. Journal of Applied Social Psychology, 32(4), 665-683.

Ajzen, I. (2002b). Residual effects of past on later behavior: Habituation and reasoned action perspectives. Personality and Social Psychology Review, 6(2), 107-122.

Ajzen, I. (2011). The Theory of Planned Behaviour: Reactions and reflections. Psychology $\mathcal{E}$ Health, 26(9), 1113-1127.

Ajzen, I. (2012). The Theory of Planned Behavior. In P.A.M. Lange, A.W. Kruglanski, \& E.T. Higgins (Eds.), Handbook of theories of social psychology (438-459). London, UK: Sage

Ajzen, I., \& Fishbein, M. (2005). The influence of attitudes on behavior. In D. Albarracín, B.T. Johnson, \& M.P. Zanna (Eds.), The handbook of attitudes (173-221). Mahwah, NJ: Erlbaum

Ajzen, I., \& Madden, T.J. (1986). Prediction of goal-directed behavior: Attitudes, intentions, and perceived behavioral control. Journal of Experimental Social Psychology, 22, 453-474.

Armitage, C.J. (2005). Can the Theory of Planned Behavior predict the maintenance of physical activity? Health Psychology, 24(3), 235-245.

Armitage, C.J., \& Conner, M. (2001). Efficacy of the Theory of Planned Behaviour: A meta-analytic review. The British Journal of Social Psychology, 40(Pt 4), 471-499.

Bandura, A. (1982). Self-efficacy mechanism in human agency. American Psychologist, 37(2), 122-147.

Bandura, A. (1992). On rectifying the comparative anatomy of perceived control: Comments on "Cognates of personal control". Applied and Preventive Psychology, 1(2), 121-126.

Bauer, I.M., \& Baumeister, R.F. (2011). Self-regulatory strength. In K.D. Vohs, \& R.F. Baumeister (Eds.), Handbook of self-regulation. Research, theory, and applications (2nd edition, 64-82). New York, London: The Guilford Press

Baumeister, R.F., Gailliot, M., DeWall, C.N., \& Oaten, M. (2006). Self-regulation and personality: How interventions increase regulatory success, and how depletion moderates the effects of traits on behavior. Journal of Personality, 74(6), 1773-1802.

Berkes, T. (2013). Az életminôség és egyes egészségviselkedések ischaemiás szívbetegségben szenvedó betegeknél a rehabilitáció után hat hónappal. Az egészségviselkedés változását befolyásoló tényezók. Doktori értekezés. Budapest: Eötvös Loránd Tudományegyetem

Blair, C., \& Ursache, A. (2011). A bidirectional model of executive functions and self-regulation. In K.D. Vohs, \& R.F. Baumeister (Eds.), Handbook of self-regulation. Research, theory, and applications (2nd edition, 300-320). New York, London: The Guilford Press

Blue, C.L. (1995). The predictive capacity of the theory of reasoned action and the Theory of Planned Behavior in exercise research: An integrated literature review. Research in Nursing \& Health, 18(2), 105-121.

Bush, G., Luu, P., \& Posner, M.I. (2000). Cognitive and emotional influences in anterior cingulate cortex. Trends in Cognitive Sciences, 4(6), 215-222.

Clarkson, J.J., Hirt, E.R., Jia, L., \& Alexander, M.B. (2010). When perception is more than reality: The effects of perceived versus actual resource depletion on self-regulatory behavior. Journal of Personality and Social Psychology, 98(1), 29-46. 
Conner, M., \& Armitage, C.J. (1998). Extending the Theory of Planned Behavior: A Review and avenues for further research. Journal of Applied Social Psychology, 28, 1429-1464.

Delpouve, J., Schmitz, R., \& Peigneux, P. (2014). Implicit learning is better at subjectively defined non-optimal time of day. Cortex, 58, 18-22.

Etter, J.-F., \& Sutton, S. (2002). Assessing "stage of change" in current and former smokers. Addiction, 97(9), 1171-1182.

Falkenstein, M., Hoormann, J., Christ, S., \& Hohnsbein, J. (2000). ERP components on reaction errors and their functional significance: A tutorial. Biological Psychology, 51 (2-3), 87-107.

Francis, J., Eccles, M.P., Johnston, M., Walker, A.E., Grimshaw, J.M., Foy, R., et al. (2004). Constructing questionnaires based on the Theory of Planned Behaviour: A manual for health services researchers. Letöltve: 2014. 03. 17-én: http:/ / openaccess.city.ac.uk/1735

Gagné, C. \& Godin, G. (2000), The Theory of Planned Behavior: Some measurement issues concerning belief-based variables. Journal of Applied Social Psychology, 30, 2173-2193.

Gailliot, M.T., \& Baumeister, R.F. (2007). The physiology of willpower: Linking blood glucose to self-control. Personality and Social Psychology Review, 11(4), 303-327.

Gailliot, M.T., Baumeister, R.F., DeWall, C.N., Maner, J.K., Plant, E.A., Tice, D.M., et al. (2007). Self-control relies on glucose as a limited energy source: Willpower is more than a metaphor. Journal of Personality and Social Psychology, 92(2), 325-336.

Gibson, E.L. (2007). Carbohydrates and mental function: Feeding or impeding the brain? Nutrition Bulletin, 32, 71-83.

Gibson, E.L., \& Green, M.W. (2002). Nutritional influences on cognitive function: Mechanisms of susceptibility. Nutrition Research Reviews, 15(1), 169-206.

Godin, G., \& Kok, G. (1996). The Theory of Planned Behavior: A review of its applications to health-related behaviors. American Journal of Health Promotion, 11(2), 87-98.

Gollwitzer, P.M. (1999). Implementation intentions: Strong effects of simple plans. American Psychologist, 54(7), 493-503.

Hagger, M.S. (2010). Self-regulation: An important construct in health psychology research and practice. Health Psychology Review, 4(2), 57-65.

Hagger, M.S., Chatzisarantis, N.L.D., \& Biddle, S.J.H. (2002). A meta-analytic review of the Theories of Reasoned Action and Planned Behavior in physical activity: Predictive validity and the contribution of additional variables. Journal of Sport E Exercise Psychology, 24(1), 3-32.

Hagger, M.S., Wood, C., Stiff, C., \& Chatzisarantis, N.L.D. (2009). The strength model of self-regulation failure and health-related behaviour. Health Psychology Review, 3(2), 208-238.

Hagger, M.S., Wood, C., Stiff, C., \& Chatzisarantis, N.L.D. (2010). Ego depletion and the strength model of self-control: A meta-analysis. Psychological Bulletin, 136(4), 495-525.

Hall, P.A., \& Fong, G.T. (2007). Temporal self-regulation theory: A model for individual health behavior. Health Psychology Review, 1(1), 6-52.

Hall, P.A., Fong, G.T., Epp, L.J., \& Elias, L.J. (2008). Executive function moderates the intention-behavior link for physical activity and dietary behavior. Psychology $\mathcal{E}$ Health, 23(3), 309-326.

Hausenblas, H.A., Carron, A.V., \& Mack, D.E. (1997). Application of the Theories of Reasoned Action and Planned Behavior to exercise behavior: A meta-analysis. Journal of Sport \& Exercise Psychology, 19, 36-51.

Hofmann, W., Friese, M., \& Wiers, R.W. (2008). Impulsive versus reflective influences on health behavior: A theoretical framework and empirical review. Health Psychology Review, 2(2), 111-137. 
Inzlicht, M., \& Gutsell, J.N. (2007). Running on empty: Neural signals for self-control failure. Psychological Science, 18(11), 933-937.

Job, V., Dweck, C.S., \& Walton, G.M. (2010). Ego depletion-Is it all in your head? Implicit theories about willpower affect self-regulation. Psychological Science, 21, 1686-1693.

Kim, M.-S., \& Hunter, J.E. (1993). Attitude-behavior relations: A meta-analysis of attitudinal relevance and topic. Journal of Communication, 43(1), 101-142.

Kraft, P., Rise, J., Sutton, S., \& Røysamb, E. (2005). Perceived difficulty in the theory of planned behaviour: Perceived behavioural control or affective attitude? British Journal of Social Psychology, 44(3), 479-496.

Kurzban, R. (2010). Does the brain consume additional glucose during self-control tasks? Evolutionary Psychology, 8(2), 244-259.

Leventhal, H., Singer, R., \& Jones, S. (1965). Effects of fear and specificity of recommendation upon attitudes and behavior. Journal of Personality and Social Psychology, 2(1), 20 29.

Lewis, M.D., \& Todd, R.M. (2007). The self-regulating brain: Cortical-subcortical feedback and the development of intelligent action. Cognitive Development, 22(4), 406-430.

Madden, T.J., Ellen, P.S., \& Ajzen, I. (1992). A comparison of the Theory of Planned Behavior and the Theory of Reasoned Action. Personality and Social Psychology Bulletin, 18(1), 3-9.

Manning, M. (2009). The effects of subjective norms on behaviour in the Theory of Planned Behaviour: A meta-analysis. British Journal of Social Psychology, 48(4), 649-705.

Marshall, S.J., \& Biddle, S.J. (2001). The transtheoretical model of behavior change: A meta-analysis of applications to physical activity and exercise. Annals of Behavioral Medicine, 23(4), 229-246.

McEachan, R.R.C., Conner, M., Taylor, N.J., \& Lawton, R.J. (2011). Prospective prediction of health-related behaviours with the Theory of Planned Behaviour: A meta-analysis. Health Psychology Review, 5(2), 97-144.

McEachan, R.R.C., Lawton, R.J., \& Conner, M. (2010). Classifying health-related behaviours: exploring similarities and differences amongst behaviours. British Journal of Health Psychology, 15(Pt 2), 347-366.

Mischel, W., Ebbesen, E.B., \& Raskoff Zeiss, A. (1972). Cognitive and attentional mechanisms in delay of gratification. Journal of Personality and Social Psychology, 21(2), 204218.

Mischel, W., Shoda, Y., \& Rodriguez, M.I. (1989). Delay of gratification in children. Science, 244(4907), 933-938.

Miyake, A., Friedman, N.P., Emerson, M.J., Witzki, A.H., Howerter, A., \& Wager, T.D. (2000). The unity and diversity of executive functions and their contributions to complex "frontal lobe" tasks: A latent variable analysis. Cognitive Psychology, 41(1), 49-100.

Muraven, M., \& Baumeister, R.F. (2000). Self-regulation and depletion of limited resources: Does self-control resemble a muscle? Psychological Bulletin, 126(2), 247-259.

Murtagh, A.M., \& Todd, S.A. (2004). Self-regulation: A challenge to the strength model. Journal of Articles in Support of the Null Hypothesis, 3(1), 19-50.

Norman, P., Conner, M., \& Bell, R. (2000). The Theory of Planned Behaviour and exercise: Evidence for the moderating role of past behaviour. British Journal of Health Psychology, 5(3), 249-261.

Ouellette, J.A., \& Wood, W. (1998). Habit and intention in everyday life: The multiple processes by which past behavior predicts future behavior. Psychological Bulletin, 124(1), 54-74. 
Paus, T. (2001). Primate anterior cingulate cortex: Where motor control, drive and cognition interface. Nature Reviews Neuroscience, 2(6), 417-424.

Plotnikoff, R.C., Lubans, D.R., Trinh, L., \& Craig, C.L. (2012). A 15-year longitudinal test of the Theory of Planned Behaviour to predict physical activity in a randomized national sample of Canadian adults. Psychology of Sport and Exercise, 13(5), 521-527.

Posner, M.I., Rothbart, M.K., Sheese, B.E., \& Tang, Y. (2007). The anterior cingulate gyrus and the mechanism of self-regulation. Cognitive, Affective \& Behavioral Neuroscience, 7(4), 391-395.

Prochaska, J.O., DiClemente, C.C., \& Norcross, J.C. (1992). In search of how people change. Applications to addictive behaviors. American Psychologist, 47(9), 1102-1114.

Rhodes, R., \& Courneya, K. (2004). Differentiating motivation and control in the Theory of Planned Behavior. Psychology, Health \& Medicine, 9(2), 205-215.

Rothman, A.J., Baldwin, A.S., Hertel, A.W., \& Fuglestad, P.T. (2011). Self-regulation and behavior change: Disentangling behavioral initiation and behavioral maintenance. In K.D. Vohs, \& R.F. Baumeister (Eds.), Handbook of self-regulation. Research, theory, and applications (2nd edition, 106-122). New York: The Guilford Press

Rotter, J.B. (1966). Generalized expectancies for internal versus external control of reinforcement. Psychological Monographs: General and Applied, 80(1), 1-28.

Rutter, D., \& Quine, L. (2002). Social cognition models and changing health behaviours. In D. Rutter, \& L. Quine (Eds.), Changing health behaviour. Intervention and research with social cognition Models (1-27). Buckingham, Philadelphia: Open University Press

Schwarzer, R. (2008). Modeling health behavior change: How to predict and modify the adoption and maintenance of health behaviors. Applied Psychology, 57(1), 1-29.

Sheeran, P. (2002). Intention-behavior relations: A conceptual and empirical review. European Review of Social Psychology, 12(1), 1-36.

Skår, S., Sniehotta, F.F., Araújo-Soares, V., \& Molloy, G.J. (2008). Prediction of behaviour vs. prediction of behaviour change: The role of motivational moderators in the Theory of Planned Behaviour. Applied Psychology, 57(4), 609-627.

Sniehotta, F.F., Schwarzer, R., Scholz, U., \& Schüz, B. (2005). Action planning and coping planning for long-term lifestyle change: Theory and assessment. European Journal of Social Psychology, 35(4), 565-576.

Symons Downs, D., \& Hausenblas, H.A. (2005). Elicitation studies and the Theory of Planned Behavior: A systematic review of exercise beliefs. Psychology of Sport and Exercise, $6(1), 1-31$.

Terry, D.J., \& O'Leary, J.E. (1995). The theory of planned behaviour: The effects of perceived behavioural control and self-efficacy. The British Journal of Social Psychology, 34(Pt 2), 199-220.

Topa, G., \& Moriano, J.A. (2010). Theory of Planned Behavior and smoking: Meta-analysis and SEM model. Substance Abuse and Rehabilitation, 1, 23-33.

Trafimow, D., Sheeran, P., Conner, M., \& Finlay, K.A. (2002). Evidence that perceived behavioural control is a multidimensional construct: Perceived control and perceived difficulty. The British Journal of Social Psychology, 41(Pt 1), 101-121.

Trope, Y., \& Liberman, N. (2003). Temporal construal. Psychological Review, 110(3), 403421.

Vohs, K.D., Baumeister, R.F., \& Schmeichel, B.J. (2013). Erratum to “Motivation, personal beliefs, and limited resources all contribute to self-control" [J. Exp. Soc. Psychol. 48 (2012) 943-947]. Journal of Experimental Social Psychology, 49(1), 183. 
Wagner, D.D., \& Heatherton, T.F. (2011). Giving in to temptation. The emerging cognitive neuroscience of self-regulatory failure. In K.D. Vohs, \& R.F. Baumeister (Eds.), Handbook of self-regulation. Research, theory, and applications (2nd edition, 41-63). New York, London: The Guilford Press

Webb, T.L., \& Sheeran, P. (2006). Does changing behavioral intentions engender behavior change? A meta-analysis of the experimental evidence. Psychological Bulletin, 132(2), 249-268.

Weinstein, N.D., Rothman, A.J., \& Sutton, S.R. (1998). Stage theories of health behavior: Conceptual and methodological issues. Health Psychology, 17(3), 290-299.

Wicker, A.W. (1969). Attitudes versus actions: The relationship of verbal and overt behavioral responses to attitude objects. Journal of Social Issues, 25, 41-47.

Zimbardo, P.G., \& Boyd, J.N. (1999). Putting time in perspective: A valid, reliable individual-differences metric. Journal of Personality and Social Psychology, 77(6), 1271-1288.

\title{
Köszönetnyilvánítás
}

A tanulmány korábbi formájában a doktori dolgozatom elméleti bevezetôjének egy részét alkotta. Szeretném megköszönni témavezetőm, Urbán Róbert, valamint Köteles Ferenc észrevételeit a tanulmány elsố változatához. Köszönettel tartozom a kézirat lektorainak alapos munkájukért és inspiráló megjegyzéseikért.

\section{Nyilatkozat érdekütközésról}

A szerző ezúton kijelenti, hogy esetében nem állnak fenn érdekütközések.

\section{From intentions to self-regulation. Models of behaviour in health behaviours}

\author{
BERKES, TÍMEA
}

Background: Predicting health behaviours is important for health psychology both because of theoretical and practical reasons; there are several models in the psychological literature with this purpose. Aim: The study starts with a traditional model based on the intentionbehaviour link (the Theory of Planned Behaviour, TPB, Ajzen, 1991), and - after a detailed discussion of the theory - reaches a model which considers the period after intention formation as self-regulation (Temporal Self-Regulation Theory, Hall \& Fong, 2007). Method: Narrative review. Results: According to meta-analyses, the extent of variance explained by the model is between $39 \%$ and $44 \%$ in the case of intention, while the explained variance ranges between $19 \%$ and $34 \%$ in the case of actual behaviour. The portion of variance explained also depends on the behaviour itself, but results have been inconsistent so far. Some debated issues concerning the model are also discussed, namely issues in connection with perceived behavioural control, the role of the two predictors of behaviour, and the components of attitude and subjective norm. Past behaviour is the best predictor of future behav- 
iour. After presenting empirical results and theoretical considerations in connection with past behaviour, the period after intention formation is discussed as a self-regulatory process. According to the strength model of self-control, self-regulatory capacity is limited, and this resource can be depleted by situations which require self-control. Brain areas regulating self-regulation are the same as the brain areas of executive function. The role of glucose as a resource of self-control has been challenged. Temporal Self-Regulation Theory integrates several theoretical considerations. In the post-intentional phase the model includes both the biological basis of self-regulatory processes and past behaviour. Intention is influenced by the temporal contingencies of the perceived benefits and costs of the behaviour. Conclusions: In the post-intentional phase, several factors can play an important role. Temporal Self-Regulation Theory is a promising theoretical framework of behaviour change; it is a current task for researchers to gather empirical evidence in connection with the model.

Keywords: behaviour change, intention-behaviour relations, self-regulation, past behaviour, Theory of Planned Behaviour, health behaviours 